\title{
Principio de proporcionalidad y delitos de peligro abstracto ${ }^{1}$
}

\author{
TERESA AGUADO-CORREA
}

taguado@us.es

GALILEU - REVISTA DE DIREITO E ECONOMIA * e-ISSN 2184-1845

Volume XX - $1^{\text {st }}$ July Julho $-31^{\mathrm{TH}}$ December Dezembro $2019 \cdot \mathrm{pp}$. 101-150

DOI: http://doi.org/10.26619/2184-1845.XX.2.6

Submitted on October 15 th $2019 \cdot$ Accepted on November 15 $15^{\text {th }}, 2019$

Submetido em 15 de Outubro, 2019 - Aceite a 15 de Novembro, 2019

RESUMEN Se analiza la compatibilidad de los delitos de peligro abstracto con los principios que integran el principio de proporcionalidad en sentido amplio: principio de idoneidad, principio de necesidad y el principio de proporcionalidad en sentido estricto (proporcionalidad abstracta y concreta). También, y dada la dimensión constitucional que adquieren estos conflictos, nos ocupamos del eventual control que puede efectuar el Tribunal Constitucional, principalmente, frente a una desmesurada intervención penal cuando se trata de comportamientos que sólo implican un peligro abstracto para el bien jurídico.

PALABRAS CLAVE idoneidad, necesidad, proporcionalidad en sentido estricto, delitos de peligro abstracto, control de constitucionalidad.

ABSTRACT The compatibility of the crimes of abstract danger is analyzed with the principles that integrate the principle of proportionality in a broad sense: principle of adequacy, principle of necessity and the principle of proportionality in the strict sense (abstract and concrete proportionality). Also, and given the constitutional dimension that these conflicts acquire, we deal with the eventual control that the Constitutional Court can carry out, mainly, in the face of an excessive criminal intervention when it comes to behaviors that only imply an abstract danger for the legal interest protected.

1 Este trabajo está publicado bajo el título "El principio de proporcionalidad en derecho penal. Especial consideración de los delitos de peligro abstracto" en el libro El principio de proporcionalidad penal, Ad Hoc, Buenos Aires, 2014. Es un resumen de la postura sostenida en mi tesis doctoral "El principio de proporcionalidad en Derecho Penal. Especial consideración de los delitos de peligro abstracto", defendida en abril de 1998 en la Universidad de Sevilla, y publicada como monografía en el año 1999 bajo el título El principio de proporcionalidad en Derecho Penal. Una versión actualizada y ampliada ha sido publicada bajo el título El principio constitucional de proporcionalidad por la Editorial Jurídica Continental, San José, 2013, publicación conforme a la cual se realizarán las citas del presente trabajo. 
KEYWORDS Adequacy, necessity, proportionality in a strict sense, abstract danger crime, constitutionality control.

\section{Introducción}

Ningún principio constitucional de los que afectan al sistema penal ha sufrido un auge tan extraordinario a nivel internacional en los últimos años como el principio constitucional de proporcionalidad. Los principales artífices de este apogeo han sido los órganos garante de las respectivas Constituciones Políticas.

En este trabajo abordamos la compatibilidad de los delitos de peligro abstracto con el principio de proporcionalidad en sentido amplio. Los que fueron denominados «hijastros de la dogmática penal» dejaron de serlo. El debate que la categoría de los delitos de peligro, y más concretamente la de los delitos de peligro abstracto, suscitó fundamentalmente en los años 80 y principios de los 90 del siglo pasado, aun cuando ya con anterioridad fueron objeto de una viva polémica, no se puede considerar aún concluido.

Si tradicionalmente se le ha prestado atención a la compatibilidad de los delitos de peligro abstracto con el principio de ofensividad, desde nuestro punto de vista no se acaban aquí los problemas de relevancia constitucional que plantea esta discutida categoría de delitos. Estos delitos presentan además problemas constitucionales puestos en relación con el resto de los subprincipios que conforman el principio de proporcionalidad en sentido amplio: principio de idoneidad, principio de intervención mínima y el principio de proporcionalidad en sentido estricto. También, y dada la dimensión constitucional que adquieren estos conflictos, hemos analizado el eventual control que puede efectuar el Tribunal Constitucional, principalmente, frente a una desmesurada intervención penal cuando se trata de comportamientos que sólo implican un peligro abstracto para el bien jurídico.

Este enfoque constitucional nos exige abordar previamente, y de forma sucinta en este trabajo, algunas cuestiones previas: la relación entre la Constitución y el Derecho penal2 ${ }^{2}$; consagración constitucional del principio de proporcionalidad 3 ; y el análisis del contenido del denominado principio de proporcionalidad en sentido amplio en Derecho penal ${ }^{4}$, teniendo muy presente en dicha labor la jurisprudencia del Tribunal Constitucional español.

\footnotetext{
2 Sobre esta relación, vid. AGUADO CORREA, El principio constitucional..., cit., pp. 29-46.

3 Vid. AGUADO CORREA, El principio constitucional..., cit., pp. 99-113.

4 El contenido de este principio en Derecho penal se analiza profusamente en AGUADO CORREA, El principio constitucional..., cit., pp. 123-267.
} 


\section{Constitución y derecho penal}

La relación existente entre la Constitución y el Derecho penal es innegable. La Constitución es expresión de los principios fundamentales que inspiran un Ordenamiento jurídico. En la base de todo texto constitucional, se encuentra latente una concepción del Derecho que informa todas las normas que componen el sistema jurídico, pudiéndose afirmar que el Derecho penal es la rama del Ordenamiento jurídico que se encuentra más ligada a la Constitución ${ }^{5}$, lo cual no es de extrañar si tenemos en cuenta que es la que en mayor medida afecta al individuo. Al ser la pena la principal consecuencia del delito, la relación entre la Constitución y el Derecho penal se acrecienta en la medida en que constituye el último recurso del poder del Estado y, por ello, se contempla generalmente en los textos constitucionales, desprendiéndose de dicha regulación consecuencias en lo que se refiere a su concepto, finalidad 6 .

Uno de los ámbitos en los que mejor puede apreciarse la relevancia de la Constitución para el Derecho penal es el de los límites al ius puniendi7: si queremos establecer límites al mismo éstos deberán derivarse del ordenamiento constitucional ${ }^{8}$. La formulación de un Código Penal que se adapte a los valores básicos de la convivencia debe empezar por el establecimiento de un sistema de garantías, de tal forma que el encabezamiento del Derecho penal se inicie por la fijación de sus límites 9 . Y es que la evolución histórica del Derecho penal no se identifica con su desaparición y sustitución por otros sistemas de control social más idóneos, sino que, por el contrario, se caracteriza por su paulatina racionalización y sometimiento a límites ${ }^{10}$. Como afirma HASSEMER, para el Derecho penal futuro se trata de hacer viable la orientación hacia el mantenimiento de los principios garantistas, no sólo para el «sistema» y el «Estado de Derecho», sino sobre todo para las personas que viven en el sistema ${ }^{11}$.

5 CARBONELL MATEU, Derecho penal: concepto y principios constitucionales, 2. ${ }^{\mathrm{a}}$ ed., Valencia, 1996, pp. 79 y ss., para quien la función del Derecho penal es la tutela de «valores o intereses con relevancia constitucional», con lo que la Constitución delimitaría no sólo de forma positiva el campo de actuación del Derecho penal, sino que, por otra parte, viene a fundamentar y limitar la actuación de los poderes públicos.

6 COBO DEL ROSAL/VIVES ANTÓN, Derecho penal. Parte General, 4. ${ }^{\text {a }}$ ed., Valencia, 1996, p. 45.

7 CUELLO CONTRERAS, Derecho penal español. Curso de iniciación. Parte General. Nociones introductorias. Teoria del delito/1, Madrid, 1996, p. 54; ARROYO ZAPATERO, «Derecho penal económico y Constitución», RP, núm. 1, julio 1997, p. 1.

8 En este sentido ÁLVAREZ GARCÍA, «Bien jurídico y Constitución», CPC, 1991, p. 18.

9 Vid., en este sentido, CÓRDOBA RODA, «Nuevas formas de delito y principio de intervención mínima», La Ley, 1996, p. 1333.

10 MORALES PRATS en QUINTERO OLIVARES, Curso de Derecho penal. Parte General, Barcelona, 1996, p. 93. Vid., también en este sentido, GARCÍA-PABLOS, Derecho penal. Introducción, Madrid, 1995, p. 58; TERRADILLOS BASOCO, en MAPELLI CAFFARENA/TERRADILLOS BASOCO, Las consecuencias juridicas del delito, $3{ }^{\mathrm{a}}{ }^{\mathrm{ed}}$., Madrid, 1996, p. 19.

11 HASSEMER, «Perspectivas del Derecho penal futuro», traducción de ANARTE BORRALLO, RP, núm. 1 (1997), p. 39. 
Principio de proporcionalidad y delitos de peligro abstracto

TERESA AGUADO-CORREA

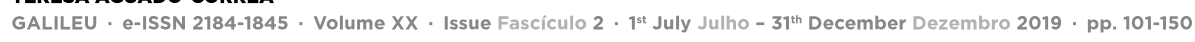




\section{Principio de proporcionalidad. Aspectos generales}

Aun cuando su origen se remonta a la Antigüedad, el principio de proporcionalidad sólo se pudo afirmar en la época de la Ilustración, cuando maduraron el resto de los demás presupuestos del Derecho penal moderno, es decir, la legalidad, la certeza, la igualdad y, especialmente, la calculabilidad y mensurabilidad de las penas ${ }^{12}$. BECCARIA, máximo representante del pensamiento ilustrado en el ámbito penal, concluyó su obra Dei delitti e delle pene afirmando: «De cuanto hasta aquí se ha dicho puede sacarse un teorema general, muy útil, pero poco conforme al uso, Legislador ordinario de las Naciones; esto es: para que la pena no sea violencia de uno o de muchos contra un particular ciudadano debe ser la pena pública, pronta, necesaria, la menor de las posibles en las circunstancias actuales, proporcionada a los delitos y dictada por las leyes» ${ }^{13}$. En el artículo 8 de la Declaración de Derechos del Hombre (1789) se decía: «La Loi ne doit établir que des peies strictement et évidemment nécessaires». El principio de proporcionalidad debe, en gran medida, su formulación actual al Tribunal Constitucional alemán (BVerfG). En los últimos años también ha sufrido un importante desarrollo, siguiendo la formulación del Tribunal Constitucional alemán, en la jurisprudencia constitucional de algunos países de Latinoamérica, como el Perú ${ }^{14}$, Colombia $^{15}$, Brasil ${ }^{16}$ o Costa Rica ${ }^{17}$.

\section{Principio de proporcionalidad en sentido amplio en derecho penal}

\section{IV.1. Introducción}

En un Derecho de la intervención como lo es el Derecho penal, las garantías del Estado de Derecho han desempeñado la función de condicionar las intromisiones y su intensidad a determinados presupuestos, así como la función de minimizar-

12 FERRAJOLI, Derecho y razón. Teoría del garantismo penal, Madrid, 1995, p. 398. Nos recuerda FERRAJOLI, nota final 150, p. 451, que la exigencia de que la pena sea proporcionada a la gravedad del delito la podemos encontrar expresada en la obra de PLATÓN, Las leyes, cuando afirma: «¿No hemos de distinguir entre el ladrón que roba mucho o poco, el que roba de lugares sagrados o profanos, ni atenderemos a tantas otras circunstancias enteramente desemejantes entre sí, como se dan en el robo, que siendo muy variadas exigen que el legislador se atenga a ellas imponiendo castigos totalmente diferentes?». En la Carta Magna de 1215 también podemos encontrar sancionado el principio de proporcionalidad, al hablar en los apartados 20 y 21 de «proporción» entre pena y transgresión. En la época intermedia es reformulado por D'Isernia en los siguientes términos: «poena debet proportionari delicto».

13 BECCARIA, Tratado de los delitos y de las penas, traducción de JUAN ANTONIO DE LAS CASAS, edición de 1774, presentación de TOMÁS Y VALIENTE, Madrid, 1993, p. 255.

14 Cfr. AGUADO CORREA, El principio constitucional..., cit., pp. 472 y ss.

15 Vid., entre otras, Sentencias C-070 de 1996; C-939 de 2002; C-121 de 2012; C-212 de 2012; C 365 de 2012.

16 Vid, por todas, Habeas Corpus 104.410, Rio Grande do Sul, Ministro Gilmar Mendes, de 6 de marzo de 2012.

17 Cfr. AGUADO CORREA, El principio constitucional..., cit., pp. 404 y ss. 
las y controlarlas. Y en este contexto, se puede afirmar que el principio central es el de la proporcionalidad de las intervenciones, que deben ser necesarias y adecuadas para lograr su objetivo y también deben ser razonables o proporcionadas en cada caso ${ }^{18}$. En el ámbito del Derecho penal, sin embargo, el principio de proporcionalidad en sentido amplio tiene un significado mucho más restringido pero no por ello menos importante que en el ámbito procesal penal o en el derecho administrativo, por diversos motivos. En primer lugar, porque de la relación de las normas penales se puede deducir que el fin que a través de las mismas se persigue es único: protección de los bienes jurídicos frente a lesiones o puestas en peligro, a través de la amenaza penal. En segundo lugar, porque este fin será alcanzado a través del medio de la desaprobación ético-social del comportamiento delictivo ${ }^{19}$. Así lo ha puesto de manifiesto el Tribunal Constitucional alemán, al afirmar que el principio de proporcionalidad adquiere un papel relevante cuando se trata de examinar un precepto penal, puesto que la mayor sanción de la que dispone el Estado es el reproche ético-social sobre un determinado comportamiento del ciudadano [BVerfGE 90, 145 (172)]. Siendo el fin del Derecho penal la protección de bienes jurídicos ${ }^{20}$, lo cual limita la amenaza penal a aquellos comportamientos que pongan en peligro o lesionen el bien jurídico, también se introduce una limitación al medio que pueda utilizar el legislador para alcanzar dicho fin. Tanto las normas redactadas por el legislador como las sanciones que en el caso concreto sean impuestas por el juez - penas, medidas de seguridad o consecuencias accesorias - han de resultar medios adecuados para luchar contra los delitos ${ }^{21}$.

Nos encontramos ante un principio que opera tanto en el momento de creación del Derecho por los legisladores como en el de su aplicación por los Jueces o Tribunales e incluso en el momento de ejecución de la pena, medida de seguridad o consecuencia accesoria. En el ámbito del Derecho penal se destaca la funcionalidad de este principio en la tipicidad, la antijuricidad y en el establecimiento del enlace material entre el delito y su consecuencia jurídica ${ }^{22}$. En primer lugar, la prohibición de exceso actuaría como límite a la criminalización de conductas que el legislador lleva a cabo a través de la creación de tipos

18 HASSEMER, «Perspectivas del Derecho penal futuro», RP, núm. 1 (1997), p. 39.

19 TIEDEMANN, Tatbestandsfunktionen im Nebenstrafrecht. Untersuchungen zu einem rechtsstaatlichen Tatbestandsbegriff, entwickelt am Problem des Wirtschaftsstrafrechts, Tübingen, 1969, p. 144; el mismo, en «Grundgesetz und Strafrecht»,40 Jahre Grundgesetz. Der Einfluß des Verfassungsrechts auf die Entwicklung der Rechtsordnung, Heidelberg, 1990, p. 172.

20 Adoptamos de esta manera la postura que sostiene tanto la doctrina mayoritaria como el Tribunal Constitucional, en torno a la función del Derecho penal.

21 RUDOLPHI, Systematischer Kommentar zum Strafgesetzbuch, I 13 Lfg. 5 Auf. (November 1990), previo al § 1, Nm. 12, expresa esta idea con la siguiente afirmación: «A la exactitud y razonabilidad del fin se le debe añadir la exactitud y razonabilidad del medio».

22 Cfr. SÁNCHEZ GARCÍA, «El principio constitucional de proporcionalidad en Derecho penal», La Ley, 1994 , p. 1118. 
penales $^{23}$, como tendremos ocasión de comprobar a lo largo de este trabajo. En segundo lugar, una vez afirmada la tipicidad de un comportamiento, en el ámbito de la antijuricidad hay que comprobar la ausencia de causas de justificación, campo en el juegan un papel fundamental los principios de necesidad y proporcionalidad ${ }^{24}$ como criterios de ponderación de intereses ${ }^{25}$, sin que quepa olvidar el principio de idoneidad ${ }^{26}$. En último lugar, hay que acudir al principio de proporcionalidad en sentido amplio para entender el enlace material entre el delito y su consecuencia jurídica ${ }^{27}$. Al poseer rango constitucional, en Derecho penal no puede exigirse su respeto exclusivamente en el ámbito de las penas sino también en el ámbito del resto de las consecuencias jurídico-penales que se pueden derivar de la comisión de un delito: las medidas de seguridad y las consecuencias accesorias. Incluso se puede afirmar que la relevancia del principio de proporcionalidad es mayor en el ámbito de las medidas de seguridad que en el ámbito de las penas ${ }^{28}$.

\section{IV.2. Consagración constitucional}

Aun cuando la mayoría de la doctrina española se muestra de acuerdo en reconocer rango constitucional al principio de proporcionalidad, no existe consenso sobre el precepto o preceptos constitucionales donde pueda considerarse consagrado, pudiéndose constatar una gran diversidad de opiniones doctrinales ${ }^{29}$. En nuestra opinión, el principio de proporcionalidad es un principio constitucional que cabe inferir de los artículos 1.1, 9.3 y 10.1 CE. No se trata, como ocurre con el principio de legalidad, de un principio contemplado como un derecho fundamental ${ }^{30}$, sino, tal y como ha expresado el Tribunal Constitucional (SSTC 55/1996 y 161/1997), un principio reconocido implícitamente en tres preceptos consti-

23 SÁNCHEZ GARCÍA, «El principio constitucional...», La Ley, 1994, pp. 1118 y 1119.

24 Cfr. AGUADO CORREA, El principio constitucional..., cit., p. 96.

25 Cfr. SÁNCHEZ GARCÍA, «El principio constitucional...», La Ley, 1994, pp. 1120 y ss.; en el seno de la doctrina alemana, RUDOLPHI, «Rechtsfertigungsgründe im Strafrecht. Ein Beitrag zur Funktion. Struktur und den Prinzipien», Gedächtnisschrift für Armin Kaufmann, Köln, 1989, pp. 389 y ss.

26 Aun cuando este principio no es destacado por los autores, es un principio del cual no se puede prescindir en algunas causas de justificación. Cfr. GÜNTHER, Strafrechtswidrigkeit und Strafrechtsausschluß..., cit., 179; más referencias doctrinales en AGUADO CORREA, El principio constitucional..., cit., pp. 95 y ss.

27 SÁNCHEZ GARCÍA, «El principio constitucional...», La Ley, 1994, p. 1122.

28 Cfr. AGUADO CORREA, El principio constitucional..., cit., pp. 97 y ss.

29 Sobre la diversidad de opiniones doctrinales vid. AGUADO CORREA, El principio constitucional..., cit., pp. 99 y ss.

30 No obstante, el Tribunal Constitucional español, apartándose de sus pronunciamientos anteriores (SSTC 55/1996 y 161/1997 y la jurisprudencia allí citada), en la controvertida Sentencia 136/1999, consideró que el principio de proporcionalidad en sentido amplio se encontraba consagrado en el art. 25.1 CE, precepto en el que contempla el principio de legalidad. A la vista de los citados antecedentes jurisprudenciales, resulta sorprendente que el Tribunal Constitucional declarase en esta Sentencia 136/1999 la inconstitucionalidad del art. 174 bis a) CP, por vulneración del derecho a la legalidad penal (art. 25.1 CE) desde la perspectiva del principio de proporcionalidad, en los siguientes términos: «se ha producido una vulneración del principio de legalidad penal en cuanto comprensivo de la proscripción constitucional de penas desproporcionadas» FJ (30). Cfr. AGUADO CORREA, El principio constitucional..., cit., p. 392. 
tucionales de gran relevancia como son aquel en el que se afirma que España se constituye en un Estado social y democrático de Derecho y propugna como valores superiores de su ordenamiento la justicia y la libertad (art. 1.1 CE); el artículo 9.3 CE, en el cual se contempla el principio de prohibición de arbitrariedad de los poderes públicos, y, finalmente, el principio de proporcionalidad se puede inferir de la dignidad de la persona proclamada en el artículo 10.1 $\mathrm{CE}^{31}$.

El principal ámbito de aplicación del principio de constitucionalidad es el de los derechos fundamentales ${ }^{32}$, por lo que no será difícil que en el ámbito de Derecho penal la falta de proporción implique un sacrificio innecesario o excesivo del derecho a la libertad reconocido en el artículo $17 \mathrm{CE}$, puesto que toda norma penal conlleva una restricción de la libertad individual (STC 105/1988) ${ }^{33}$, con la consiguiente posibilidad de interponer un recurso de amparo $^{34}$.

\section{IV.3. Contenido del principio de proporcionalidad}

La discrepancia en torno al principio de proporcionalidad no se agota en la determinación de los preceptos constitucionales en los cuales se puede considerar consagrado este principio, sino que también se extiende al posible contenido ${ }^{35}$.

Desde nuestro punto de vista, se puede hablar de un principio de proporcionalidad en sentido amplio que se descompone en tres subprincipios o, en la terminología del Tribunal Constitucional ${ }^{36}$, hablar de un principio cuya aplicación es regida por

31 La importancia de estos tres artículos es tal que GARRIDO FALLA, Comentarios a la Constitución española, 2. ${ }^{\text {a }}$ ed., Madrid, 1985, p. 186, ha afirmado que conforman «la trilogía de los que realizan la positivización de principios generales que constituyen una de las características de la Constitución». Cfr. AGUADO CORREA, El principio constitucional..., cit., p. 111 y ss.

32 Aun cuando el Tribunal Constitucional, español reconoce que el ámbito propio de aplicación del principio de proporcionalidad es el de los derechos fundamentales, no llega hasta el punto de derivar el principio de proporcionalidad de los derechos fundamentales, tal y como ha hecho el BVerfG.

33 En la BVerfGE 90, 145 (172), el Tribunal Constitucional alemán ha puesto de relieve que para determinar la proporcionalidad de toda norma penal, la sanción penal con la que se amenaza ha de ser analizada en relación con el artículo 2.2.2 GG, en el cual ser reconoce la inviolabilidad del derecho a la libertad. Vid. LAGODNY, Strafrecht vor den Schranken der Grundrechte. Die Ermächtigung zum strafrechtlichen Vorwurf im Lichte der Grundrechtsdogmatik dargestellt am Beispiel der Vorfeldkriminalisierung, Tübingen, 1996 p. 130.

34 Esta posibilidad ha sido avalada por lo afirmado por el Alto Tribunal en la Sentencia de 2 de octubre de 1997 (STC 161/1997 FFJJ 8 y 9).

35 Sobre la polémica doctrinal vid. AGUADO CORREA, El principio constitucional..., cit., pp. 114 y ss.

36 La STC 66/1995, de 8 de mayo, es la primera resolución en la que el Tribunal Constitucional español habla expresamente de la idoneidad, necesariedad y proporcionalidad como requisitos o condiciones necesarios para superar el juicio de proporcionalidad, si bien es en el Fundamento Jurídico 6 de la Sentencia 55/1996, donde el Tribunal Constitucional reconoce la descomposición del principio de proporcionalidad en tres subprincipios, tal y como ya venía ocurriendo en la jurisprudencia del BVerfG desde hacía años, así como en una parte minoritaria de la doctrina penal española. Sobre la doctrina jurisprudencial del TC vid. AGUADO CORREA, El principio constitucional..., cit., p. 115 y ss. 
tres condiciones: idoneidad, necesidad y proporcionalidad en sentido estricto. Tal y como ha concretado el Tribunal Constitucional estas condiciones, cabe decir que en virtud del primer subprincipio, la medida ha de ser apta para alcanzar el fin pretendido. La necesidad de la medida implica que no se podía optar por otra igualmente eficaz, que no gravase o lo hiciese en menor medida los derechos afectados. En último lugar, el sacrificio que se impone al derecho correspondiente debe guardar un razonable equilibrio o proporción con los bienes jurídicos que se pretenden salvaguardar.

Los tres subprincipios en los que cabe descomponer el principio de proporcionalidad en sentido amplio, los concretaremos en el ámbito del Derecho penal de la siguiente forma. En primer lugar, el principio de idoneidad requiere que el Derecho penal sea apto para la tutela del bien jurídico y que la medida adoptada sea adecuada para conseguir la finalidad que se persigue. El principio de necesidad en Derecho penal se concreta, por una parte, en el principio de exclusiva protección de bienes jurídicos y, por otra, en el principio de intervención mínima con los dos postulados que lo integran: ultima ratio y carácter fragmentario del Derecho penal. El principio de proporcionalidad en sentido estricto viene a coincidir con el principio de proporcionalidad de las penas tal y como ha sido entendido tradicionalmente por la doctrina.

\section{IV.3.A. Principio de idoneidad}

\section{Formulación}

El nacimiento del denominado principio de idoneidad, eficacia o utilidad ${ }^{37}$ se sitúa en von Lisz $^{38}$, apareciendo posteriormente reflejado también en la obra de MAYER ${ }^{39}$ cuando al establecer los criterios de intervención penal, exigía que el bien jurídico reuniese tres cualidades: «merecedor de protección», estar «necesitado de protección» y ser «capaz de protección $\gg^{40}$. Es a partir de esta capacidad de protección cuando se puede hablar de idoneidad o inidoneidad del Derecho penal, capacidad que habrá que valorar teniendo en cuenta todas

37 MIR PUIG, Derecho penal. Parte General, $4 .^{\text {a }}$ ed., Barcelona, 1996, p. 88, habla del principio de utilidad de la intervención penal como principio limitador del ius puniendi propio de un Estado social. FERNÁNDEZ RODRÍGUEZ, «Los límites del ius puniendi», ADPCP, 1994, p. 101, se refiere a él como principio de oportunidad o de utilidad del Derecho.

38 VON LISZT, Lehrbuch des deutschen Strafrechts, 21. ${ }^{\mathrm{a}} / 22$. $^{\mathrm{a}}$ ed., Berlín/Leipzig, 1919, pp. 6 y 21.

39 MAYER, M. E., Der Allgemeiner Teil des deutschen Strafrechts, 2. ${ }^{a}$ ed., Heidelberg, 1923, 23

40 LUZÓN PEÑA, Curso de Derecho penal. Parte General I, Madrid, 1996, p. 84. SILVA SÁNCHEZ, Aproximación al Derecho penal contemporáneo, Barcelona, 1992, p. 289, estima que la «susceptibilidad» de protección penal puede entenderse incluida en la «necesidad», puesto que si el bien no es apto para la protección penal, es obvio que no necesita esa protección. 
las condiciones reales del sistema penal ${ }^{41}$. No todos los bienes jurídicos que reúnen las dos primeras cualidades son también aptos o idóneos para ser protegidos penalmente, ofreciéndose como ejemplo de estos bienes jurídicos la moral sexual. ${ }^{42}$. En virtud de este principio de idoneidad, el Derecho penal únicamente puede y debe intervenir cuando sea mínimamente eficaz e idóneo para prevenir el delito, debiéndose evitar su intervención cuando político-criminalmente éste se muestre inoperante, ineficaz o inadecuado o cuando incluso se muestre contraproducente para la prevención de delitos ${ }^{43}$.

Teniendo en cuenta el presupuesto de que el fin de las normas que prevén penas es la protección de bienes jurídicos a través de la prevención, tanto general como especial ${ }^{44}$, habrá que excluir del Derecho penal aquellas penas que se manifiesten como ineficaces por no servir a la prevención. Por otra parte, también pueden darse supuestos en los que una concreta tipificación del delito se muestra ineficaz, existiendo una elevada «cifra negra» de comisión de delitos ${ }^{45}$. El principio de idoneidad implica, además de la necesidad de que la pena sea apta para la tutela del bien jurídico - para evitar conductas que lo pongan en peligro o lo lesionen-, que la pena sea «cualitativamente adecuada para conseguir la finalidad». Ya en este sentido afirmaba BECCARIA: «Otro principio que sirve admirablemente para estrechar más y más la importante conexión entre el delito y la pena; este es, que se ella conforme, quanto se pueda, a la naturaleza del mismo delito»46.

No se agota aquí el significado del principio de idoneidad, sino que este principio también implica que el mismo ha de ser realizable a través de la normas de Derecho procesal ${ }^{47} \mathrm{y}$ de Derecho penitenciario ${ }^{48}$. De nada serviría una regulación penal si ésta no puede llevarse a la práctica ${ }^{49}$.

41 SILVA SÁNCHEZ, Aproximación al Derecho..., cit., p. 289.

42 MUÑOZ CONDE, en MUÑOZ CONDE/GARCÍA ARÁN, Derecho penal. Parte General, Valencia, 1996, p. 83.

43 GÜNTHER, Strafrechtswidrigkeit und Strafunrechtsausschluß..., cit., p. 186; LUZÓN PEÑA, Curso de Derecho..., cit., p. 84; FERNÁNDEZ RODRÍGUEZ, «Los límites del ius puniendi», ADPCP, 1994, p. 101.

44 Una vez negado que la retribución fuese el fin de las penas, afirma BECCARIA (Tratado de los delitos..., cit., p. 60): «El fin, pues, no es otro que impedir al reo causar nuevos daños a sus ciudadanos, y retraher los demás de la comisión de otros iguales.»

45 Como ejemplo se ofrece la regulación del aborto antes de que se introdujese el artículo 417 bis ACP - punible sin excepción alguna-, regulación que debido a que no era compartida por gran parte de la sociedad, carecía de eficacia preventivo-general.

46 BECCARIA, Tratado de los delitos..., cit., p. 108; CARBONELL MATEU, Derecho penal: concepto..., cit., p. 199.

47 ARMENTA DEU, «Pena y proceso: fines comunes y fines específicos», en Política criminal y nuevo Derecho penal. Libro homenaje a Claus Roxin, Barcelona, 1997, p. 215.

48 En este sentido, RUDOLPHI, Systemmatischer Kommentar, ,cit., previos al § 1, Nm. 13; HASSEMER, Theorie und soziologie des Verbrechens. Ansätze zu einer prazisorientierten Rechtsgutslehre, Frankfurt am Main, 1973, pp. 196 y ss.

49 No debemos olvidar que en el artículo 24.2 de la Constitución Española se reconoce el derecho fundamental a un proceso sin dilaciones indebidas. 


\section{Respeto del principio de idoneidad}

El debate sobre la idoneidad del Derecho penal adquirió un gran protagonismo en el seno de la doctrina alemana, debido al planteamiento realizado por la «Escuela de Frankfurt» sobre la inidoneidad del Derecho penal para hacer frente a los problemas que se derivan de lo que se denomina «sociedad de riesgo ${ }^{50}$. En este sentido, HASSEMER previene de los inconvenientes de lo que se entiende por un Derecho penal «eficaz»y, desde luego, no le falta razón. Ante el acuciante sentimiento que tiene la sociedad de amenaza por la creciente violencia que se da en el seno de la misma, se recurre al Derecho penal y al Derecho procesal penal, esperándose de los mismos una ayuda eficaz ante situaciones de necesidad y también que garanticen la seguridad de los ciudadanos ${ }^{51}$. Con ello se provoca una mayor dureza del Derecho penal y del Derecho procesal penal, puesto que se pretende afrontar de un modo efectivo el creciente sentimiento de inseguridad. Por una parte, la Política criminal «moderna» se caracteriza por la creación de nuevos delitos y agravación de las penas de los ya existentes; por otra parte, el Derecho penal amplía su ámbito de actuación a los sectores que la opinión pública considera más amenazados: el medio ambiente, la economía, las drogas, el terrorismo, la delincuencia organizada. Se trata de proteger bienes jurídicos colectivos que pueden, según este autor, justificar cualquier tipo de conminación penal y para cuya protección se utiliza normalmente la técnica del peligro abstracto. Esta Política Criminal desemboca en un debilitamiento de la vinculación del Derecho penal a los principios que lo limitan y se minimizan los presupuestos de la pena con el empleo de la técnica de los delitos de peligro abstracto. Ello hace olvidar al legislador que un Derecho penal contundente tiene sus costos «y se paga con la renuncia a principios políticamente valiosos y difíciles de mantener ${ }^{52}$. Al prescindir de principios tan importantes como el principio de proporcionalidad en sentido amplio, el principio de culpabilidad o el principio in dubio pro reo, el Derecho penal aumenta su eficacia y responde así a las inquietudes sociales ${ }^{53}$.

50 El primero en utilizar esta expresión fue el sociólogo alemán BECK en su monografía Risikogesellschaft. Auf dem Weg in eine andere Moderne, Frankfurt a. M., 1986. Esta expresión, que en palabras de KUHLEN, «Zum Strafrecht der Risikogesellschaft», GA, 1994, p. 347, «en los últimos años ha hecho furor», ha sido adoptada en el seno de la dogmática penal.

51 HASSEMER, «El destino de los derechos del ciudadano en un Derecho penal “eficaz”», EPC, XV (1990-1991), p. 189.

52 HASSEMER, «El destino de los derechos...», EPC, XV (1990-1991), p. 197.

53 PRITTWITZ, Strafrecht und Risiko. Untersuchungen zur Krise von Strafrecht und Kriminalpolitik in der Risikogesellschaft, Frankfurt am Main, 1993, p. 370, afirma que muestra de que el Derecho penal no constituye un medio idóneo para hacer frente a los problemas generados por la sociedad de riesgo, es que en ninguno de los campos nuevos de actuación del Derecho penal se pueden demostrar resultados visibles. 


\section{IV.3.B. Principio de necesidad en derecho penal}

\section{Introducción}

El Derecho penal es necesario cuando lo exige la protección de bienes jurídicos, si bien no todo bien jurídico ha de convertirse en un bien jurídico penal, al ser el concepto de bien jurídico más amplio que el de bien jurídico penal. Por otra parte, el Derecho penal no es necesario frente a todo ataque a bienes jurídicos penalmente tutelados, sino tan sólo frente a los ataques más graves. Ello nos lleva a afirmar que el principio de necesidad se concreta, en el ámbito del Derecho penal, en el principio de exclusiva protección de bienes jurídicos y en el principio de intervención mínima con las dos manifestaciones de este principio: el principio de subsidiariedad y el principio de fragmentariedad. Si bien el principio de necesidad adquiere especial relevancia en el momento legislativo, en el momento de selección de las conductas a incriminar, también opera en el momento de aplicación de la ley penal: tanto el hecho de recurrir a la amenaza a través de la conminación penal como en su caso la gravedad de la pena ha de justificarse en la necesidad de protección de bienes jurídicos.

\section{Principio de exclusiva protección de bienes jurídicos}

La mayoría de la doctrina admite como uno de los límites al ius puniendi el denominado principio de exclusiva protección de bienes jurídicos. En virtud del mismo, el Derecho penal tan sólo ha de intervenir cuando se trata de proteger bienes jurídicos (penales). Constituye una de las garantías del Derecho penal moderno ${ }^{54}$ que no sólo explica la función del Derecho penal (protección de bienes jurídicos) ${ }^{55}$, sino que limita y circunscribe la intervención punitiva del Estado ${ }^{56}$. Además, el Derecho penal no puede incriminar cualquier conducta, sino tan sólo aquellas que lesionen o pongan en peligro el bien jurídico, correspondiéndose de esta forma el principio de exclusiva protección de bienes jurídicos con el principio de ofensividad o lesividad 57 , el cual se usa para expresar el conocido aforismo

54 SILVA SÁNCHEZ, Aproximación al Derecho..., cit., p. 267. Si bien se trata de una garantía del Derecho penal moderno, no ha sido tan fácil su aceptación en los diversos ordenamientos.

55 El propio Tribunal Constitucional asigna en la STC 105/1988, de 8 de junio, esta función al Derecho penal al afirmar que «la restricción de la libertad individual que toda norma comporta» sólo puede tener lugar «con la finalidad de dotar de la necesaria protección a valores, bienes o intereses que sean constitucionalmente legítimos en un Estado social y democrático de Derecho».

56 GARCÍA-PABLOS, Derecho penal..., cit., p. 264.

57 En este sentido se pronuncian GARCIA-PABLOS, Derecho penal..., cit., p. 264. Por su parte, COBO/VIVES, Derecho penal.., cit., p. 290, afirman que el principio de ofensión o «lesividad» ha de ser reconducido de forma inexorable al principio de legalidad, puesto que se encuentra limitado y condicionado por este principio. SILVA SÁNCHEZ, Aproximación al Derecho..., cit., p. 291, estima el principio de lesividad u ofensividad como parte integrante del principio de protección fragmentaria, en el cual inciden tanto consideraciones de proporcionalidad como consideraciones de utilidad. 
nullum crimen sine iniuria, es decir, que todo delito comporta la lesión o puesta en peligro de un bien jurídico ${ }^{58}$.El principio de exclusiva protección de bienes jurídicos permite, por lo tanto, la exclusión del ámbito del Derecho penal, por un lado, de las incriminaciones a través de las cuales se pretenden proteger meros valores éticos o morales ${ }^{59}$, sin que por ello se desconozca que los bienes jurídicos penales puedan ser también bienes morales, pero requieren algo más para merecer la protección por parte del Derecho penal ${ }^{60}$. Por otro lado, el principio de protección exclusiva de bienes jurídicos, y más concretamente el principio de ofensividad, permite excluir aquellas acciones que en concreto se muestran inofensivas para el bien jurídico protegido ${ }^{61}$.

El carácter de límite al ius puniendi que venimos propugnando de este principio, se ha visto enturbiado en buena parte por la polémica suscitada, y aún no zanjada, en torno al concepto de bien jurídico. La capacidad o incapacidad del concepto de bien jurídico para servir de límite al ius puniendi depende del criterio por el que se opte para la selección de los bienes protegibles penalmente ${ }^{62}$, convirtiéndose así la discusión sobre el bien jurídico en «primordial cuestión político-criminal» ${ }^{63}$. Para algún autor, incluso el problema de selección de bienes jurídicos a proteger se convertiría en el problema central del Derecho penal ${ }^{64}$. Son dos las corrientes principales que tienden a dotar de un contenido material al concepto de bien jurídico para que pueda ejercer la función de límite del ius puniendi, sin que ninguna de ellas esté libre de toda objeción: por una parte, nos encontramos con las teorías sociológico-funcionalistas y, por otra, con las teorías constitucionalistas.

También hay algunos autores que ante la dificultad de establecer positivamente qué ha de ser protegido penalmente, se inclinan por determinar qué ha de ser protegido penalmente a través de un proceso de carácter negativo, es decir, establecer un método a través del cual se determinen aquellos bienes jurídicos que no son merecedores de tutela penal. Antes que ofrecer un concepto abstracto de bien jurídico, que plantee los problemas que

58 No hay que entender esta puesta en peligro como la exigencia de un peligro concreto, cfr. AGUADO CORREA, El principio constitucional..., cit., p. 132, n.p.p. 42.

59 COBO/VIVES, Derecho penal..., cit., p. 290; GARCÍA-PABLOS, Derecho penal..., cit., p. 265.

60 MIR PUIG, Derecho penal..., cit., p. 91. ROXIN, Strafrecht. Allgemeiner Teil, cit., § 2/12, afirma que la exclusión de las contravenciones morales del Derecho penal no significa que también algunos «sentimientos» (Empfindungen) deban ser protegidos penalmente.

61 Haremos referencia al principio de exclusiva protección de bienes jurídicos cuando se trate de imponer un límite al legislador y hablaremos de principio de ofensividad cuando hagamos referencia al límite a la actividad de interpretación y aplicación de las leyes por parte del poder judicial.

62 Así lo ha puesto de manifiesto expresamente en nuestra doctrina, entre otros, GÓMEZ BENÍTEZ, «Sobre la teoría del "bien jurídico" (aproximación al ilícito)», RFDUCM, 69 (1983), p. 87.

63 QUINTERO OLIVARES, Curso de Derecho penal..., cit., p. 244. También MUÑOZ CONDE, en MUÑOZ CONDE/ GARCÍA ARÁN, Derecho penal..., cit., p. 81, considera que la protección de bienes jurídicos a través del Derecho penal constituye un problema de Política Criminal antes que una cuestión dogmática.

64 MORALES PRATS, en QUINTERO OLIVARES, Curso de Derecho penal..., cit., p. 91. 
se vienen exponiendo para ejercer la función de garantía o límite al ius puniendi, prefieren ofrecer criterios delimitadores hablando de un Derecho penal mínimo ${ }^{65}$.

Para que el bien jurídico pueda desempeñar esta función y no únicamente una función interpretativa o sistemática, es imprescindible distinguir entre «bien jurídico» y ratio legis, puesto que si confundimos ambos conceptos, el bien jurídico perdería su utilidad como criterio limitador, como se puso de manifiesto con la propuesta realizada por HONIG ${ }^{66}$. La finalidad objetiva de la norma no tiene por qué coincidir con el bien jurídico protegido por la norma ${ }^{67}$. Además, la finalidad puede alcanzarse o no, pero el bien jurídico siempre ha de resultar lesionado o puesto en peligro ${ }^{68}$.

Por lo que respecta a la doctrina jurisprudencial del TC sobre los criterios de selección de los bienes jurídico-penales. En este sentido adquiere especial relevancia el pronunciamiento contenido en el Fundamento Jurídico 6 de la Sentencia del Tribunal Constitucional, de 28 de marzo (STC 55/1996): «La respuesta a esta cuestión debe partir inexcusablemente del recuerdo de la potestad exclusiva del legislador para configurar los bienes penalmente protegidos...En el ejercicio de su competencia de selección de los bienes jurídicos que dimanan de un determinado modelo de convivencia social y de los comportamientos atentatorios contra ellos, así como la determinación de las sanciones penales necesarias para la preservación del referido modelo, el legislador goza, dentro de los límites establecidos

65 En la obra de FERRAJOLI, Derecho y razón... cit., p. 479, encontramos expresadas estas ideas, incluso con cierta contundencia. Según este autor, todos los delitos de peligro abstracto o delitos de peligro presunto deberían ser reestructurados sobre la base del principio de lesividad, como delitos de lesión o al menos de peligro concreto. En este sentido, las propuestas de PORTILLA CONTRERAS, «Principio de intervención mínima y bienes jurídicos colectivos», CPC, núm. 39 (1989); ZUGALDÍA ESPINAR, Fundamentos de Derecho penal, 3. ${ }^{\text {a }}$ ed., Valencia, 1993, pp. 52 y ss.

66 Este autor alemán, en su obra Die Einwilligung des Verletzten. Die Geschichte des Einwilligungsproblems und die Methodenfrage, 1919, p. 94, citado por RUDOLPHI, «Los diferentes aspectos del concepto de bien jurídico», Nuevo Pensamiento Penal, 1975, pp. 331 y 332, concibió el bien jurídico protegido como «el fin que ha reconocido el legislador en las prescripciones penales, en su más breve formulación».

67 Por ello resulta criticable, desde nuestro punto de vista, el pronunciamiento del Tribunal Constitucional en la Sentencia 55/1996, en la que da primacía a la finalidad, sin que le importe el bien jurídico protegido por la norma, en estos términos: «Con independencia de cuál sea el bien jurídico protegido por la norma analizada (LO 8/1984), lo cierto es que la finalidad de protección explícita e inmediata de la misma recae sobre...». Afortunadamente, el Tribunal Constitucional ha rectificado esta postura en la STC 161/1997, al afirmar: «conviene precisar como prius lógico de este enjuiciamiento los bienes o intereses que la norma cuestionada pretende proteger» (FJ 10).

68 Cuando COBO/VIVES, Derecho penal..., cit., p. 295, estudian la función exegética del bien jurídico, destacan la insuficiencia del mismo como criterio rector de la interpretación, proponiendo acudir a otros criterios. Entre estos criterios incluyen la ratio legis, puesto que no siempre se trata de un criterio idéntico al del bien jurídico: no siempre la protección penal otorgada a un determinado bien jurídico constituye la finalidad última perseguida por el legislador cuando decide incriminar determinados comportamientos. Estos autores nos recuerdan que, en ocasiones, se protege un bien jurídico para obtener determinados resultados «más o menos conectados remotamente con él». De ello derivan que incluso admitiendo que la ratio legis cumpla un papel en la interpretación de los tipos, es de carácter subsidiario porque a lo que hay que atender es al tipo de injusto, el cual consiste en la lesión o puesta en peligro del bien jurídicamente protegido. 
en la Constitución, de un amplio margen de libertad, margen de libertad que deriva de su posición constitucional y, en última instancia, de su específica legitimidad democrática. No sólo cabe afirmar, pues, que, como no puede ser de otro modo en un Estado social y democrático de Derecho, corresponde en exclusiva al legislador el diseño de la política criminal, sino también que, con la excepción que imponen las citadas pautas elementales que emanan del texto constitucional, dispone para ello de plena libertad.»

Pero el Tribunal Constitucional realiza otra afirmación en esta Sentencia (55/1996) que puede resultar de interés para concretar estas pautas elementales que ha de tener en cuenta el legislador, y más aún si tenemos en cuenta que ha vuelto a pronunciarse en términos muy parecidos en la Sentencia 161/1997 (FJ 10): «... debemos precisar en primer lugar cuál es el bien jurídico protegido por la norma cuestionada o, mejor, cuáles son los fines inmediatos y mediatos de protección de la misma. Esta premisa constituye un prius lógico para la determinación de si el legislador ha incurrido en el exceso manifiesto en el rigor de las penas vulnerador del artículo 17.1 CE, al introducir un sacrificio patentemente inidóneo, innecesario o desproporcionado del derecho a la libertad; a la par que permite descartar toda posibilidad de sujeción mínima al principio de proporcionalidad si el sacrificio de la libertad que impone la norma persigue la preservación de bienes o intereses, no sólo, por supuesto, constitucionalmente proscritos, sino ya también, socialmente irrelevantes (STC 111/1993)».

En vista de la doctrina del Tribunal Constitucional acerca del principio de exclusiva protección de bienes jurídicos, cabe concluir que carecen de toda justificación aquellas posturas que niegan cualquier valor o referencia al marco ofrecido por la Constitución. El legislador, como ha reconocido el Tribunal Constitucional, posee plena libertad para el diseño de la política criminal y la selección de bienes jurídicos, pero ha de proceder dentro de los límites establecidos por la Constitución. Por ello, y dada la restricción de libertad que comporta toda norma penal, únicamente podrá proteger penalmente valores, bienes o intereses constitucionalmente legítimos y socialmente relevantes. Este límite - constitucionalmente legítimo e importancia social - no será difícil de superar por el legislador y poco tendrá que decir al respecto el máximo órgano garante de la Constitución. Aparece, pues, el principio de protección exclusiva de bienes jurídicos como un límite «relativo» en la elección de los bienes jurídicos a tutelar ${ }^{69}$. Ni incluso la relevancia constitucional de un determinado bien jurídico aparece como un verdadero límite al ius puniendi. Un ejemplo lo encontramos en el campo del Derecho penal económico ${ }^{70}$.

69 En este sentido DOLCINI/MARINUCCI, «Costituzione e politica dei beni giuridici», RIDPP, 1994, pp. 334 y 335.

70 Vid. ARROYO ZAPATERO, «Derecho penal económico y Constitución», RP, 1997, pp. 3 y 4. Cfr. ulteriores referencias en AGUADO CORREA, El principio constitucional..., cit., pp. 161 y ss. 
Como hemos señalado anteriormente, el principio de exclusiva protección de bienes jurídicos se corresponde con el principio de ofensividad en el sentido de que todo delito ha de comportar la lesión o puesta en peligro de un bien jurídico, exigiendo en el momento de aplicación de la ley penal que el comportamiento concreto que se está juzgando haya lesionado o puesto en peligro el bien jurídico. En este sentido se habla de una «doble influencia» del principio de lesividad ${ }^{71}$ : por una parte, sobre el legislador, que es el que elige el bien jurídico a tutelar; por otra parte, sobre el juez, quien no se puede conformar con la subsunción formal del hecho en el comportamiento descrito por la norma, sino que tendrá que comprobar que dicho comportamiento ha lesionado o ha puesto en peligro el bien jurídico protegido a través de dicha norma, y en el caso de que no sea así, deberá declarar su atipicidad. Adquiere de esta manera el bien jurídico un papel central en la interpretación de los tipos penales ${ }^{72}$.

A pesar de la importancia práctica de esta vertiente del principio que venimos comentando, son varios los supuestos en los que la jurisprudencia ha desconocido la vigencia del principio de ofensividad como límite en el momento de interpretación y aplicación de la ley. Esto ha ocurrido cuando se ha enfrentado con supuestos de anticipación de la protección penal: tentativa y delitos de peligro abstracto ${ }^{73}$.

Desde nuestro punto de vista, el bien jurídico como límite al ius puniendi adquiere mayor importancia en el momento de interpretación y aplicación de la ley que en el momento legislativo debido al amplio margen que posee el legislador para elegir, y a veces incluso configurar, los bienes jurídicos que son merecedores de la protección penal, con el único límite de que no estén constitucionalmente proscritos y sean socialmente relevantes. Aparte, es mayor el control por parte del Tribunal Constitucional que se puede llevar a cabo sobre la actividad de los Jueces y Tribunales que la que se puede realizar en relación con la actividad del legislador. Puesto que el criterio del «bien jurídico constitucionalmente legítimo y socialmente relevante», no se muestra como un límite suficiente para la actividad del legislador, es necesario buscar y tener en cuenta otros criterios ulteriores.

71 Expresión adoptada por GARCÍA RIVAS, El poder punitivo en el Estado democrático, Cuenca, 1996, p. 49, del autor italiano PALAZZO.

72 En este sentido, en la STC 111/1993, el Alto Tribunal asume la idea de que el principio de exclusiva protección de bienes jurídicos opera tanto en el momento legislativo como en el judicial, conectándola con el principio de interpretación conforme a la Constitución. De esta manera se conectaría la garantía material del bien jurídico con la garantía formal del principio de legalidad, adquiriendo esta última una dimensión material. GARCÍA RIVAS, El poder punitivo..., cit., p. 49.

73 Cfr. AGUADO CORREA, El principio constitucional..., cit., pp. 166 y ss. 


\section{Principio de intervención mínima: principio de subsidiariedad y principio de fragmentariedad}

Una vez afirmado que tan sólo son merecedores de tutela penal los bienes constitucionalmente legítimos y socialmente relevantes frente a comportamientos que los lesionen o los pongan en peligro, cabe plantearse la cuestión de si el legislador está obligado a protegerlos penalmente. A esta cuestión debe responderse de una forma negativa, salvo para los casos en los que así se contemple expresamente. La doctrina contemporánea se muestra casi unánime en considerar que la existencia de un bien jurídico merecedor de tutela penal no es suficiente para justificar la creación de un tipo penal: el bien jurídico debe necesitar dicha protección penal para llegar a convertirse en un bien jurídico penal74. Podemos afirmar que en el plano político-criminal los conceptos de merecimiento y necesidad de pena, tal y como vienen siendo concebidos por la mayoría de la doctrina ${ }^{75}$, se asumen como fórmula concentrada de los principios jurídicos constitucionalmente consagrados - que delimitan el horizonte de la criminalización ${ }^{76}$-, y más concretamente de alguno de los subprincipios que conforman el principio de proporcionalidad en sentido amplio ${ }^{77}$ : el principio de idoneidad y el principio de necesidad. Así, el concepto de merecimiento de pena expresa el principio de protección exclusiva de bienes jurídicos y el principio de fragmentariedad, en tanto que el concepto de necesidad de pena no es sino una expresión de los principios de idoneidad y de subsidiariedad.

El principio de intervención mínima estaría integrado por los postulados del carácter fragmentario del Derecho penal y el carácter de ultima ratio o subsidiario del Derecho penal $^{78}$. En virtud de este último, el Derecho penal tan sólo debe ser utilizado como ultima

74 La doctrina se muestra casi unánime en este sentido. Cfr. para las referencias doctrinales AGUADO CORREA, El principio constitucional..., cit., p. 176, n.p.p. 205.

75 En relación con el contenido de los conceptos de merecimiento y necesidad de pena, a pesar de que la mayoría de los autores coinciden sobre el mismo, cfr. AGUADO CORREA, El principio constitucional..., cit., p. 178, n.p.p. 207, algunos autores introducen una serie de matizaciones. Así, SCHÜNEMANN, «Der strafrechtliche Schutz von Privatgeheimnissen», ZStW, 1978, pp. 54 y ss.; o VOLK, «Entkriminalisierung durch Strafwürdigkeitskriterien jenseits des Deliktsaufbaus», ZStW, 1985, p. 899.

76 Vid., en este sentido, VOLK, «Entkriminalisierung durch Strafwürdigketiskriterien...», ZStW, 1985, pp. 873 y 874; DACOSTAANDRADE, «Merecimiento y necesidad de tutela penal como referencias de una doctrina teleológico-racional del delito», en Fundamentos de un sistema europeo de Derecho penal. Libro Homenaje a Claus Roxin, Barcelona, 1995, p. 165. Para ulteriores referencias doctrinales vid. AGUADO CORREA, El principio constitucional..., cit., p. 179, n.p.p. 209.

77 Tan sólo en el caso de que se adopte la postura de SHÜNEMANN, «Methodologische Prolegomena zur Rechtsfindung im Besonderen Teil des Strafrechts», en Festschrift für Bockelman, München, 1979, pp. 129 y ss., sobre la concepción del merecimiento y de la necesidad de pena, podemos afirmar que estos conceptos se asumen como fórmula concentrada del principio constitucional de proporcionalidad en sentido amplio: principio de idoneidad, principio de necesidad y principio de proporcionalidad en sentido estricto. Cfr. AGUADO CORREA, El principio constitucional...,cit., p. 179, n.p.p. 209.

78 La mayoría de la doctrina considera que tanto el carácter fragmentario del Derecho penal, así como el carácter de ultima ratio, constituyen concreciones o manifestaciones del principio de intervención mínima, cfr. AGUADO CORREA, El principio constitucional...,cit., p. 182. 
ratio, es decir, cuando no existan medios menos lesivos para proceder a la protección del bien jurídico en cuestión. Con la expresión carácter fragmentario del Derecho penal se quiere hacer referencia a que el Derecho penal no ha de sancionar todos los ataques a los bienes jurídicos penales, sino tan sólo aquellos que resulten más graves para los bienes jurídicos fundamentales.

El Tribunal Constitucional, por su parte, se ha referido en repetidas ocasiones a la vigencia del principio de intervención mínima o a alguno de sus postulados ${ }^{79}$. Cuando en la Sentencia 55/1996 el Tribunal Constitucional se refiere al requisito de la necesidad habla de «la existencia o no de medidas alternativas menos gravosas, pero de la misma eficacia que la analizada».

El principio de subsidiariedad del Derecho penal implica que éste tan sólo debe ser utilizado únicamente allí donde sea imprescindible para la protección de la sociedad $^{80}$, lo cual significa su utilización, exclusivamente, para la protección de aquellos bienes jurídicos que sean indispensables para la convivencia de los hombres y que no pueden ser protegidos eficazmente por otros medios distintos al Derecho penal ${ }^{81}$. Únicamente en caso de que estos mecanismos se muestren como insuficientes para la protección del bien jurídico, el legislador podrá acudir a las sanciones penales. Pero no olvidemos que la utilización de las sanciones penales requiere una comprobación previa: que el comportamiento que se pretende amenazar con estas sanciones es idóneo para lesionar o poner en peligro el bien jurídico en cuestión, que nos encontremos ante un comportamiento merecedor de pena ${ }^{82}$. En caso contrario, el recurso a la pena resultaría más dañoso

79 En la Sentencia 53/1985 hablaba de «establecer un sistema legal para la defensa de la vida que suponga una protección efectiva de la misma y que, dado el carácter fundamental de la vida, incluya también como última garantía las normas penales. Ello no significa que dicha protección haya de revestir carácter absoluto...». En el Fundamento Jurídico 4 de la STC 241/1991 se afirma «... que ha de estimarse desproporcionada respecto del fin perseguido por la norma penal y que pugna con el principio de intervención mínima que preside el orden penal...».

80 KAUFMANN, «Subsidiaritätsprinzip und Strafrecht», en Grundfragen der gesamten Strafrechtswissenschaft. Festschrift fürHenkel zum 70 Geburtstag, Berlín, New York, 1974, p. 102; JESCHECK, Leipziger Kommentar. Großkommentar, 1. ${ }^{a}$ Lieferung. Einleitung, Nm. 3; JESCHECK/WEIGEND, Lehrbuch des Strafrechts., cit., § 4, II, 2, p. 26. En la BVerfGE 39, 1 (47), se afirma que «la norma penal representa, en cierta medida, la ultima ratio del instrumental del legislador».

81 KAUFMANN, «Subsidiaritätsprinzip und Strafrecht», en Grundfragen der gesamten Strafrechtswissensschaft. Festschrift für Henkel, p. 102; RUDOLPHI, en Systematischer Kommentar..., cit., previo § 1, Nm. 14; JESCHECK, en Leipziger Kommentar..., Einleitung, Nm. 3; BVerfGE 88, 203 (258). La Corte constitucional italiana ha subrayado que entre los «límites sustanciales» con los que se encuentra el legislador a la hora de criminalizar, está el «principio de subsidiariedad, en virtud del cual, la criminalización, constituyendo la ultima ratio, debe intervenir en tanto que el resto de las ramas del ordenamiento jurídico no ofrezcan una tutela adecuada a los bienes jurídicos» (Sentencia de 25 de octubre de 1989).

82 Como acertadamente ha puesto de manifiesto RUDOLPHI, Systematischer Kommentar..., cit., previos al § 1, Nm. 11a, el hecho de afirmar que la función del Derecho penal consiste en la protección de bien jurídico, no conlleva que cualquier tipo penal que persiga este fin se encuentra sin más legitimado constitucionalmente. GÜNTHER, «Die Genese eines Straftatbestandes. Eine Einführung in Fragen der Strafgesetzgebungslehre», JuS, 1978, pp. 9 
que útil y sería ilegítimo ${ }^{83}$. La necesidad de tutela penal significa, además de que la tutela penal es adecuada y necesaria para la prevención de la dañosidad social, que la intervención penal en el caso concreto no va acompañada de efectos secundarios desproporcionadamente lesivos, de consecuencias accesorias negativas ${ }^{84}$. En este sentido también se ha pronunciado el Tribunal Constitucional alemán, para quien las consecuencias accesorias negativas pueden llegar a cuestionar la aptitud general de la norma penal ${ }^{85}$.

El problema de la elección entre los distintos mecanismos se ve acrecentado por la insuficiencia de los datos procedentes de investigaciones sociológico-empíricas, concernientes a en qué medida el Derecho penal es necesario para conseguir los fines de prevención y en qué medida las sanciones civiles o administrativas o los mecanismos de control social, siendo igualmenteidóneos y eficaces para conseguir los mismos, constituyen una alternativa menos gravosa $^{86}$. Las investigaciones empíricas, al igual que ocurre con el principio de idoneidad, constituyen un elemento fundamental para conseguir la realización del principio de intervención mínima, puesto que se trata de principios de naturaleza empírica frente a la naturaleza eminentemente normativa del principio de proporcionalidad en sentido estricto ${ }^{87}$.

y ss.; GRASSO, «Die Vorverlegung des Strafrechtsschutzes durch Gefährdungsund Unternehmensdelikte im italianischen Strafrecht», en Beiheft zur ZStW, 1987, pp. 86 y 87, comienza las consideraciones de lege ferenda sobre los delitos de peligro, afirmando la necesidad de buscar límites a la anticipación de la tutela penal en la Constitución. Vid. también FIANDACA, «Il "bene giuridico" come problema teorico e como criterio di politica criminale», RIDPP, 1982, pp. 79 y ss. MUÑOZ CONDE, en MUÑOZ CONDE/GARCÍA ARÁN, Derecho penal..., cit., p. 81, afirma que cuando existen dudas sobre si una determinada conducta es merecedora de pena debe elegirse la vía de la impunidad o la despenalización (in dubio pro libertate).

83 Vid. en este sentido FIANDACA/MUSCO, Diritto penale. Parte Generale, 5. ${ }^{\mathrm{a}}$ ed., Bologna, 1992, p. 7.

84 Se pronuncian en este sentido HASSEMER/MUÑOZ CONDE, Introducción a la Criminología..., cit., pp. 65 y ss. SILVA SÁNCHEZ, Aproximación al Derecho..., cit., 289; GARCÍA-PABLOS, «Sobre el principio de intervención mínima...», en Estudios penales y jurídicos..., cit., p. 259, citando a SILVA SÁNCHEZ; SCHÜNEMANN, «Methodologische Prolegomena zur Rechtsfindung im Besonderen Teil des Strafrechts», en Festschrift für Bockelmann, München, 1979, p. 129; OTTO, «Konzeption und Grundsätze des Wirtschatsstrafrechts (einschließlich Verbraucherschutz)», ZStW, 1984, p. 362; DA COSTA ANDRADE, «Merecimiento de pena y necesidad de tutela...», en Fundamentos de un sistema europeo..., cit., p. 164.

85 BVerfGE 88, 203 (265 y ss.).

86 Cfr. DÖLLING, «Generalprävention durch Strafrecht», ZStW, 102 (1990), pp. 19 y 20; SILVA SÁNCHEZ, Aproximación al Derecho..., cit., pp. 19 y 20; WEIGEND, «Bewältigung von Beweisschwierigkeiten durch Ausdehnung des materiallen Strafrechts?», Festschrift für Triffterer zum 65 Geburtstag, Wien-New York, 1996, p. 709; ZUGALDÍA ESPINAR, Fundamentos de Derecho..., cit., p. 241; DA COSTA ANDRADE, «Merecimiento de pena y necesidad de tutela penal...», en Fundamentos de un sistema europeo..., cit., p. 164; LAGODNY, Strafrecht vor den Schranken..., cit., p. 362.

87 Destacan la naturaleza empírica del principio de idoneidad y de necesidad, frente a la naturaleza normativa del principio de proporcionalidad en sentido estricto, LERCHE, Übermaß und Verfassungsrecht. Zur Bindung des Gesetzgebers an die Grundsätze der Verhältnismäßigkeit und der Erforderlichkeit, Köln 1961, pp. 19 y ss.; HIRSCHBERG, Der Grundsatz der Verhältnismässigkeit, Göttingen, 1981, pp. 59 y ss. y 158 y ss.; GÜNTHER, Straftrechtswidrigkeit und Strafunrechtsauschluß, cit., pp. 190 y ss.; LAGODNY, Strafrecht vor den Schranken..., cit., pp. 179 y ss.; GONZÁLEZ-CUÉLLAR SERRANO, Proporcionalidad y derechos fundamentales..., cit., p. 155; SÁNCHEZ GARCÍA, «El principio constitucional de proporcionalidad en Derecho penal», La Ley, 1994, p. 1118. 
No obstante, ante la insuficiencia de las investigaciones empíricas es necesario acudir a otros criterios, encontrándose entre ellos la propia experiencia del legislador: es, por consiguiente, esta insuficiencia la que propicia la excesiva prerrogativa de decisión que se le otorga al legislador ${ }^{88}$. En este sentido, el propio Tribunal Constitucional ha señalado que el juicio de necesidad corresponde al legislador y que el amplio margen de libertad del que goza responde, en parte, a la complejidad de la tarea (STC 55/1996, FJ 8). Por supuesto, el legislador, a diferencia de lo que le ocurre al Juez o Tribunal, no ha de atender al criterio del menoscabo de los derechos de la concreta persona, sino que debe partir del menoscabo puede sufrir la totalidad de los destinatarios de la norma ${ }^{89}$.

Además del carácter empírico de este principio, podemos afirmar que nos encontramos ante un principio comparativo, en tanto que, a diferencia de lo que ocurre en el principio de aptitud y en el de proporcionalidad en sentido estricto, el legislador ha de buscar medidas alternativas menos gravosas pero igualmente eficaces ${ }^{90}$. Este último aspecto es muy importante: no se trata de buscar una alternativa menos gravosa, sino una alternativa menos gravosa igualmente eficaz o idónea. El Tribunal Constitucional así lo ha reconocido en la STC 55/1996 cuando se refiere al control que él puede llevar a cabo «... acerca de la existencia o no de medidas alternativas menos gravosas pero de la misma eficacia que la analizada...» (FJ 8), y lo ha reiterado en la STC 161/1997 al afirmar que «las medidas alternativas han de ser, pues, palmariamente de menor intensidad coactiva y de una funcionalidad manifiestamente similar a la que se critique por desproporción» (FJ 11)

Al igual que sucedía con el principio de exclusiva protección de bienes jurídicos, el principio de subsidiariedad tampoco nos ofrece un catálogo de bienes jurídicos a proteger, sino tan sólo supone un límite negativo para el legislador, quien en todo momento es libre de no atender al mismo. La cuestión es que cuando existan dudas sobre si existe un medio menos lesivo y grave que el penal para dotar de protección a un determinado bien jurídico, el legislador posee un amplio ámbito de decisión, con lo cual el principio de subsidiariedad es más una orientación político-criminal (Richtlinie) que una imposición ${ }^{91}$. Se trata de una cuestión de decisiones político-criminales; de hasta qué punto el legislador ha de convertir un ilícito

88 LAGODNY, Strafrecht vor den Schranken..., cit., p. 180. El Tribunal Constitucional alemán ha afirmado que en ocasiones son suficientes consideraciones de practicabilidad y efectividad, BVerfGE 68, 193 (219).

89 Lo recuerda en el seno de la doctrina alemana, LAGODNY, Strafrecht vor den Schranken..., cit., pp. 345 y 365 . En el seno de nuestra doctrina, ARROYO ZAPATERO, «Derecho penal económico y Constitución», RP, núm. 1 (1997), p. 5 .

90 Vid. en este sentido lo afirmado en el FJ 8 STC 55/1996 y por GONZÁLEZ-CUÉLLAR, Proporcionalidad y derechos fundamentales en el proceso penal, Madrid, 1990, p. 189.

91 Vid. ROMANO, «"Merecimiento de pena", "Necesidad de pena" y teoría del delito», en Fundamentos de un sistema europeo de Derecho penal. Libro homenaje a Claus Roxin, Barcelona, 1995, p. 142; LAGODNY, Strafrecht vor den Schranken..., cit., p. 366. 
penal en un ilícito administrativo o bien dejarlo sin sanción alguna ${ }^{92}$. Pero siempre que el legislador atienda en la medida de lo exigible al principio de subsidiariedad, se facilitará una intervención penal racional, practicable y efectiva ${ }^{93}$.

En virtud del principio de fragmentariedad, el Derecho penal no debe proteger a los bienes jurídico-penales frente a cualquier tipo de ataque, sino únicamente frente a aquellos que resulten más graves o peligrosos, ya sea por razones objetivas, ya por razones subjetivas $^{94}$. Como ya dijera ROXIN, seguramente nada contribuye más al aumento de la criminalidad que la penalización de los hechos de mínima gravedad ${ }^{95}$. El olvido del respeto del principio de fragmentariedad por parte del legislador conduce a tal inflación punitiva que provoca la degradación de la función de la pena ${ }^{96}$.

En el principio de fragmentariedad no sólo inciden consideraciones utilitaristas, como ocurre fundamentalmente con el principio de idoneidad y de subsidiariedad, sino que también inciden en él consideraciones de proporcionalidad ${ }^{97}$. Eso no significa, desde nuestro punto de vista, que el carácter fragmentario se corresponda con el principio de proporcionalidad en sentido estricto, si bien tampoco cabe desconocer que en los casos en los que el legislador no ha respetado el principio de fragmentariedad tampoco respetará el principio de proporcionalidad en sentido estricto ${ }^{98}$. El carácter fragmentario del Derecho penal constituye una concreción o uno de los postulados que integran el principio de intervención mínima, y cuando se alude al mismo se hace referencia a la necesidad de que el Derecho penal no sancione todas las conductas lesivas de los bienes jurídicos por él protegidos, sino aquellas que resulten más peligrosas para los mismos. Cuando se alude al principio de proporcionalidad en sentido estricto se hace referencia a la exigencia de proporcionalidad entre la gravedad de la pena y la gravedad del injusto, exigencia que sólo de una forma parcial se tiene en cuenta cuando se habla de carácter fragmentario.

92 ROXIN, Strafrecht. Allgemeiner Teil..., cit., § 2, XI, 31, p. 25.

93 Habla QUINTERO OLIVARES, Curso de Derecho..., cit., p. 69, de los principios de racionalidad, practicabilidad y efectividad.

94 La formulación de este principio varía muy poco de unos autores a otros, vid. AGUADO CORREA, El principio constitucional..., cit., p. 203 , n.p.p. p. 309.

95 ROXIN, «Sinn und Grenzen staatlicher Strafe», JuS, 1966, pp. 14 y ss.

$96 \mathrm{COBO} / \mathrm{VIVES}$, Derecho penal..., cit., p. 78, afirman que con razón reclamaba VON LISZT la restauración de la vigencia de la regla «minima non curat praetor».

97 Vid., en este sentido, SILVA SÁNCHEZ, Aproximación al Derecho..., cit., p. 246, n.p.p. 284.

98 ARROYO ZAPATERO, «Derecho penal económico y Constitución», RP, núm. 1 (1997), p. 6, sostiene que la proporcionalidad en sentido estricto es lo que se invoca cuando se habla del carácter fragmentario o del merecimiento de pena de un comportamiento. 


\section{Principio de necesidad de la pena}

Del principio de intervención mínima no sólo se deriva que el Derecho penal no debe intervenir donde no es necesario porque el bien no necesita ser tutelado o porque puede serlo por medios menos gravosos, sino que del mismo también se derivan una serie de consecuencias en el momento de interpretación y aplicación de las leyes penales ${ }^{99}$. Para los casos en los que no sea necesario castigar o no sea necesario castigar con una pena tan grave, el Código Penal ha de prever mecanismos que permitan prescindir de la pena o que permitan sustituirla por otra menos grave o incluso por medidas de otra índole ${ }^{100}$. El propio Tribunal Constitucional, en la Sentencia de 15 de octubre de 1982 (STC 62/1982, FJ 5), proyecta la exigencia de necesidad de pena tanto sobre el plano de la conminación penal abstracta como sobre la imposición concreta de la pena.

\section{IV.3.C. Principio de proporcionalidad en sentido estricto}

\section{Introducción}

Junto al merecimiento y la necesidad de pena constituye un requisito indispensable para considerar punible un determinado comportamiento, que exista una proporción entre la pena y el delito. Por lo tanto, la pena habrá de aparecer, en abstracto y en concreto, tanto merecida como necesitada y proporcionada ${ }^{101}$. No se trata una exigencia novedosa, sino que ya reclamaba expresamente la necesidad de proporción entre los delitos y las penas BECCARIA $^{102}$. El Tribunal Constitucional español alude al mismo como «la vertiente del principio de proporcionalidad que se refiere a la comparación entre la entidad del delito y la entidad de la pena (proporcionalidad en sentido estricto)» (STC 55/1996, FJ 9). Desde nuestro punto de vista, el principio de proporcionalidad en sentido estricto implica una relación

99 Destacan la importancia de considerar el ámbito propio de incidencia del principio de intervención mínima en el momento de interpretación y aplicación de la ley, COBO/VIVES, Derecho penal..., cit., p. 79; ARROYO ZAPATERO, «Fundamento y función del sistema penal: el programa penal de la Constitución», RJCLM, núm. 1 (1987), pp. 104 y 105; CARBONELL MATEU, Derecho penal: concepto..., cit., p. 200; MORILLAS CUEVA, Curso de Derecho penal español. Parte General, Madrid, 1996, p. 41; SILVA SÁNCHEZ, Aproximación al Derecho..., cit., p. 247, distingue una manifestación externa y otra interna del principio de subsidiariedad. En virtud de esta última, se deberá prescindir de una pena siempre que quepa esperar parecidos efectos preventivos de otra sanción penal menos gravosa.

100354 COBO/VIVES, Derecho penal..., cit., p. 79; ARROYO ZAPATERO, «Fundamento y función del sistema penal...», RJCLM, núm. 1 (1987); SILVA SÁNCHEZ, Aproximación al Derecho.., cit., p. 248, afirma que resulta obligado prescindir de la ejecución de la pena, si ello no merma la prevención general, en virtud de la vigencia del principio de intervención mínima. Sobre las manifestaciones de este principio, vid. AGUADO CORREA, El principio constitucional..., cit., pp. 217.

101 En el mismo sentido, LUZÓN PEÑA, «La relación del merecimiento de pena y de la necesidad de pena con la estructura del delito», en Fundamentos de un sistema europeo..., cit., p. 120.

102 BECCARIA, De los delitos y de las penas..., cit., pp. 28 y 29. 
de proporcionalidad entre la gravedad del injusto y la gravedad de la pena en el momento legislativo; en el momento judicial, que la pena resulte proporcionada a la gravedad del hecho concreto cometido.

El hecho de que entre la pena y el delito no exista relación natural alguna no impide que la pena deba ser adecuada a éste en alguna medida. Entre los mismos existe un nexo legal y convencional, siendo ésta la razón por la que le corresponde al legislador en un primer momento y posteriormente al juez, la elección de la cantidad y la calidad de la pena en relación con la naturaleza y la gravedad del hecho ${ }^{103}$. Lo cierto es que hay que reconocer la heterogeneidad que existe entre la pena y el delito ${ }^{104}$ y que solamente son criterios pragmáticos basados en consideraciones de oportunidad los que sirven al legislador para determinar la relación de proporción que deba guardar un comportamiento penalmente típico con la sanción que se le asigna (STC 55/1996, FJ 6; STC 161/1997, FJ 12). No obstante, de lo que no cabe duda es que, aun cuando se afirme que es imposible medir la gravedad del injusto individualmente considerado, es posible afirmar, atendiendo al principio de proporcionalidad en sentido estricto, que, desde el punto de vista interno, si dos delitos se castigan con la misma pena, es que el legislador los considera de gravedad equivalente; en tanto que si la pena prevista para un delito es más severa que la prevista para otro, el primer delito es considerado por el legislador más grave que el segundo. De lo dicho se deriva que, si desde el punto de vista externo, dos delitos no son considerados de la misma gravedad, considerándose uno más grave que el otro, y se sancionan ambos con la misma pena o el que se considera más grave se sanciona con una pena menor, se estaría vulnerando el principio de proporcionalidad en sentido estricto ${ }^{105}$.

$\mathrm{Al}$ abarcar el estudio de este principio es muy importante distinguir los dos ámbitos en los que actúa, el legislativo y el judicial, y así lo ha manifestado reiteradamente el propio Tribunal Constitucional ${ }^{106}$, quien se ha encargado de subrayar que el principio de proporcionalidad es ante todo de un principio dirigido al legislador (STC 65/1986). En tanto que la exigencia de proporcionalidad abstracta entendida como proporción entre la gravedad del injusto y la gravedad de la pena con la que éste se conmina se dirige al legislador, la exigencia de proporcionalidad concreta entendida como la necesaria proporción entre la gravedad

103 Vid. en este sentido FERRAJOLI, Derecho y razón..., cit., p. 398.

104 Señala FERRAJOLI, Derecho y razón..., cit., p. 451, que uno de los autores más críticos con la posibilidad de comparar la pena con el delito fue BOVIO, quien trató de demostrar analíticamente el carácter ilusorio de cualquier cálculo dirigido a establecer una proporción entre la entidad de la pena y la entidad del delito.

105 Vid. en este sentido FERRAJOLI, Derecho y razón..., cit., p. 402. Esto también se puede deducir de lo afirmado por el Tribunal Constitucional en la Sentencia de 2 de octubre de 1997, en el Fundamento Jurídico decimotercero.

106 En la Sentencia 111/1993, FJ 3, distingue claramente los distintos ámbitos en los que opera el principio de proporcionalidad. 
del hecho concreto cometido y la pena aplicada al autor, tiene como destinatario al Juez o Tribunal. Pasamos a referirnos separadamente a algunos de los problemas que el principio de proporcionalidad estricto plantea en el momento legislativo y en el momento judicial.

\section{Proporcionalidad abstracta}

La libertad del legislador penal se encuentra sujeta, por consiguiente, al respeto del valor de justicia del Estado de Derecho, de la interdicción de la arbitrariedad y de la dignidad de la persona, pero siempre que los respete posee un amplio poder de decisión. En este sentido, el principio de proporcionalidad de las penas es una fórmula vacía en tanto que no se establezcan los criterios de proporcionalidad que son constitucionalmente legítimos ${ }^{107}$. Por consiguiente, hay que traducir el principio de proporcionalidad en una serie de directivas más precisas para el legislador, encontrándonos ante una tarea ciertamente delicada, a pesar de la simplicidad estructural de este principio ${ }^{108}$. Con carácter general, se puede afirmar que la gravedad de la pena ha de ser proporcional a la gravedad del hecho antijurídico, a la gravedad del injusto, siendo fundamental la gravedad intrínseca del hecho, es decir, el desvalor de acción y desvalor de resultado ${ }^{109}$.Tradicionalmente se ha reconocido que la importancia del bien jurídico agredido es un factor esencial, si bien no el único que habrá de tener en cuenta el legislador a la hora de determinar la pena, ya que no puede desconocer el grado de la ofensa al bien jurídico protegido ${ }^{110}$, es decir, la gravedad del ataque. Ésta puede ser considerada tanto bajo el aspecto extensivo, es decir, el número de bienes a los que afecta ${ }^{111}$, como bajo el aspecto intensivo. Ya que en virtud del principio de proporcionalidad en sentido estricto debe existir una relación de proporcionalidad entre la gravedad de la sanción y la gravedad de la ofensa, si la ofensa no reúne un cierto nivel de gravedad, es decir, si es exigua, no puede seguir considerándose proporcional a la sanción penal: «Minima non curat praetor» ${ }^{112}$. Por este motivo, es por el que sostenemos que el principio

107 En este sentido se manifiestan BACIGALUPO, «iTienen rango constitucional las consecuencias del principio de culpabilidad?», La Ley, 1982, p. 941; GARCÍA ARÁN, Los criterios de determinación de la pena en el Derecho español, Barcelona, 1982, p. 212.

108 Vid. lo afirmado por DOLCINI, «Sanzione penale o sancione amministrativa: problemi di scienza della legislazione», RIDPP, 1984, p. 613. BAURMANN, Zweckrationalität und Strafrecht: Argumente für ein tatbezogenes Massnahmerecht, Opladen, 1987, p. 255

109 LUZÓN PEÑA, Curso de Derecho..., cit., p. 85; el mismo, «Principio de igualdad, Derecho penal de hecho y prevención especial: equilibrio y tensiones», en Estudios penales, cit., p. 308.

110 ANGIONI, Contenuto e funzioni del concetto di bene giuridico, Milano, 1983, cit., pp. 205 y ss.; CARBONELL MATEU, Derecho penal: concepto..., cit., p. 203; DOLCINI, «Sanzione penale o sanzione amministrativa...», RIDPP, 1984, p. 613, afirma que junto con el rango del bien jurídico agredido, juega un papel decisivo la gravedad de la ofensa al bien jurídico; MANTOVANI, Diritto Penale. Parte Generale, 3. ${ }^{2}$ edizione, Padova, 1992,, p. 753, habla del «grado y la cantidad de la ofensa».

111 A este aspecto hace referencia el Tribunal Constitucional en el FJ 13 de la Sentencia de 2 de octubre de 1997.

112 ANGIONI, Contenutto e funzioni..., cit., p. 209. 
de insignificancia responde fundamentalmente a la exigencia del respeto del principio de proporcionalidad en sentido estricto: no se puede seguir considerando proporcional la pena prevista por el legislador para determinados comportamientos, cuando nos encontremos ante supuestos en los que el contenido de injusto es mínimo. Para estos supuestos se debe prever la posibilidad de que el Juez deje de aplicar la pena por desproporcionada ${ }^{113}$. En relación con la gravedad de la ofensa nos interesa destacar lo afirmado por el Tribunal Constitucional en la Sentencia de 2 de octubre de 1997 (FJ 13): «No siempre el legislador considera en el CP vigente de menor gravedad o merecedores de menor sanción los comportamientos de incidencia más lejana en el bien finalmente protegido que los que afectan de una manera más inmediata. El peligro abstracto o remoto puede merecer un castigo mayor que el próximo...». Por lo tanto, y en virtud de lo manifestado por el Tribunal Constitucional, no es contrario al principio de proporcionalidad estricto amenazar con una pena más grave los comportamientos que suponen un peligro abstracto de un bien jurídico, frente a aquellos que lo ponen en peligro concreto.

Otro factor que influye es el elemento subjetivo del desvalor de la acción: el dato de que el hecho haya sido cometido dolosa o imprudentemente habrá de ser tenido en cuenta a la hora de determinar la proporcionalidad entre delito y pena, en cuanto demostrativo de la mayor o menor gravedad del delito, respectivamente ${ }^{114}$. El legislador no puede sancionar con la misma pena el ataque doloso o imprudente a un mismo bien jurídico.

Para un sector doctrinal, otro de los criterios que debe tener en cuenta el legislador en la determinación de la pena, es la trascendencia social del hecho: el legislador no puede ser ajeno a la importancia social del hecho, a la «nocividad social» del ataque del bien jurídico, de manera que en un Estado democrático, el legislador debe ajustar la gravedad de las penas a la trascendencia que para la sociedad tienen dichos hechos ${ }^{115}$.Tanto el grado de ejecución

113 Sobre el principio de insignificancia vid. AGUADO CORREA, El principio constitucional, cit., pp. 23 y ss.

114 MUÑOZ CONDE, en MUÑOZ CONDE/GARCÍA ARÁN, Derecho penal..., cit., p. 85; OCTAVIO DE TOLEDO, Sobre el concepto de Derecho Penal, Madrid, 1984, p. 364; HASSEMER, Fundamentos de Derecho penal, Barcelona, 1984, pp. 280 y 281; GARCÍA RIVAS, El poder punitivo..., cit., p. 61; GIMBERNAT ORDEIG, «iTiene un futuro la dogmática jurídico-penal», en Estudios de Derecho penal, cit., p. 154; LUZÓN PEÑA, Curso de Derecho..., cit., pp. 85 y 87 ; Por el contrario, ROXIN, «QQué queda de la culpabilidad en Derecho penal?», CPC, núm. 30 (1986), p. 674, afirma que «el principio de culpabilidad posibilita, además, una graduación del marco penal según si el autor ha actuado dolosa o imprudente; permite también, en el seno de estas categorías, nuevas graduaciones de la pena, que se fundan en si el autor actuó con dolo directo de primer grado, de segundo grado o eventual, o con imprudencia temeraria»; también GARCÍA RIVAS, El poder punitivo..., cit., p. 60, considera que la graduación de la respuesta penal, según los grados de participación interna en el delito, constituye uno de los postulados del principio de culpabilidad.

115 Ésta no es una idea nueva, sino que ya fue expresada por BECCARIA, De los delitos y de las penas, cit., p. 35. al comenzar el capítulo que lleva por rúbrica «Errores en la graduación de las penas». Vid., en este sentido, MIR PUIG, Introducción a las bases del Derecho penal. Concepto y método, Barcelona, 1976, p. 159; el mismo, en Derecho penal..., cit., p. 100; GARCÍA-PABLOS, Derecho penal, Introducción, cit., p. 291; SILVA SÁNCHEZ, Aproximación al Derecho..., cit., p. 260; ARROYO ZAPATERO, «Fundamento y función del sistema penal...», RJCLM, núm. 1 (1987), p. 105. 
como las formas de participación en el delito son criterios que el legislador ha de tener en cuenta cuando establece la gravedad de la pena.

Sin embargo, a pesar de la simplicidad que ofrece a primera vista el problema de la proporcionalidad de la pena, como afirmó DORADO MONTERO ${ }^{116}$, éste resulta más complicado de lo que en un principio pudiera pensarse, puesto que no es otro que el problema de la finalidad penal, ya que la pena proporcionada equivale a la pena adecuada al fin. Esta idea la expresó en los siguientes términos: «Me parece que el problema de la proporcionalidad o justicia de las penas, dentro del propio espíritu de los que hablan de él, va resultando más complicado de lo que pudiera creerse. Y es que semejante problema no es otro que el de la finalidad penal, toda vez que pena proporcionada vale lo mismo que pena adecuada al fin por la misma perseguido; y siendo variadísimos y a menudo hasta antitéticos los fines que con la pena se quieren obtener, forzosamente tiene que resultar difícil la organización del respectivo sistema de medios penales ${ }^{117}$.

Y así lo ha considerado en parte el Tribunal Constitucional, en el FJ 6 de la Sentencia 55/1996, y lo ha reiterado en el FJ 9 de la Sentencia de 2 de octubre de 1997, al afirmar que «... el legislador, al establecer las penas, carece, obviamente, de la guía de una tabla precisa que relacione unívocamente medios y objetivos, y ha de atender no sólo al fin esencial y directo de protección al que responde la norma, sino también a otros fines legítimos que puede perseguir con la pena y a las diversas formas en que la misma opera y que podrían catalogarse como sus funciones o fines inmediatos: a las diversas formas en que la conminación abstracta de la pena y su aplicación influyen en el comportamiento de los destinatarios de la norma - intimidación, eliminación de la venganza privada, consolidación de las convicciones éticas generales, refuerzo del sentimiento de fidelidad al ordenamiento, resocialización, etc. - y que se clasifican doctrinalmente bajo las denominaciones de prevención general y prevención especial». Como se desprende de estos pronunciamientos, el legislador, a la hora de establecer las penas, ha de atender tanto a los fines de prevención general, positiva y negativa, como a los de prevención especial - resocialización-. Por consiguiente, en la conminación penal abstracta, si bien el legislador ha de partir de criterios de proporcionalidad entre el injusto y la pena, su decisión debe incorporar además criterios de

116 «Sobre la proporción penal», RGLJ, 1916, p. 39 .

117 DORADO MONTERO, «Sobre la proporción penal», RGLJ, 1916, p. 39. Critica este autor - p. 10 - que al implicar la idea de proporcionalidad una comparación y afirmarse que la pena ha de guardar proporción con el delito por el cual se aplica, se la considera grosso modo como el pago de una deuda que con el delito se contrae, siendo ésta la concepción retributiva. Pero ya el propio BECCARIA afirmó: «La verdadera medida de la proporcionalidad es el daño social del delito», prescindiendo de la idea estrictamente retributiva. 
prevención general y de prevención especial ${ }^{118}$. La consideración de criterios de prevención general en el momento legislativo se debe a que es ésta la función fundamental de la pena en el momento de conminación penal; la inclusión de criterios de prevención especial no es más que una consecuencia de la necesidad de vigencia de los principios de resocialización y de humanidad de las penas en las tres fases de la pena y no de manera exclusiva a la fase de imposición de la pena. Ahora bien, ¿qué relación existe entre la proporcionalidad y los fines de la pena? Como venimos reiterando, desde nuestro punto de vista, la exigencia de proporcionalidad es de carácter constitucional y se puede inferir del valor de justicia del Estado de Derecho, de la interdicción de la arbitrariedad de los poderes públicos y de la dignidad de la persona, constituyendo, por consiguiente, un límite constitucional a la función preventiva de la pena compatible con la misma ${ }^{119}$. Por este motivo, no compartimos la postura de aquellos que consideran la proporcionalidad como un postulado de la idea de retribución ${ }^{120}$ que, además, sirve a la necesidades de prevención ${ }^{121}$, ni la de aquellos autores que entienden la proporcionalidad entre la gravedad del injusto y la gravedad de la pena como una exigencia de la prevención general ${ }^{122}$, o la de aquellos otros que incluso sostienen que la proporcionalidad puede derivarse exclusivamente de la prevención general $^{123}$. Por otra parte, tampoco compartimos los planteamientos de quienes son partidarios de la prevención general positiva como fundamento de la pena y consideran que uno de los argumentos en favor de la misma frente a la prevención general intimidatoria, es que resulta más idónea para incorporar en su seno los contenidos de los principios que limitan la intervención penal, tales como el principio de proporcionalidad, el de humanidad... ${ }^{24}$. La teoría de la prevención general entendida de una forma correcta encerraría, según estos autores, dentro de sí misma, su propia limitación jurídico-estatal ${ }^{125}$.Lo más rechazable de esta postura es que en el supuesto de que se consideren los principios limitadores de la pena como elementos o componentes de la función de prevención general positiva, pierden

118 QUINTERO OLIVARES, Curso de Derecho..., cit., p. 539; GARCÍA ARÁN, en MUÑOZ CONDE/GARCÍA ARÁN, Derecho penal..., cit., p. 553, no incluye la prevención especial. Para esta autora, en el momento de individualización legal de la pena predominan criterios de prevención general y proporcionalidad.

119 En el mismo sentido, aun cuando infieran el principio de proporcionalidad de otros artículos de la CE, OCTAVIO DE TOLEDO, Sobre el concepto..., cit., p. 367; SILVA SÁNCHEZ, Aproximación al Derecho..., cit., pp. 236 y 280.

120 Los partidarios de la idea de la retribución alegan que ésta es irrenunciable porque es la única, o la mejor manera de exigir y garantizar la proporcionalidad entre delitos y penas. Vid. BAJO FERNÁNDEZ, «Algunas observaciones sobre la teoría de la motivación de las normas», en Estudios penales, I, Madrid, 1977, pp. 38 y ss.

121 Vid. CEREZO MIR, Curso de Derecho penal español. Parte General, I, Introducción, 5. ${ }^{a}$ ed., Madrid, 1996, p. 28; GARCÍA-PABLOS, Derecho penal, Introducción, cit., p. 291.

122 Los autores de la Ilustración sostenían que más eficaz que la pena severa o cruel es la pena proporcionada al delito. Vid. BECCARIA, De los delitosy de las penas, cit., pp. 28 y ss.

123 MIR PUIG, Derecho penal..., cit., p. 100.

124 Tampoco comparte este planteamiento SILVA SÁNCHEZ, Aproximación al Derecho..., cit., pp. 237 y 259.

125 HASSEMER, Fundamentos del Derecho penal..., cit., p. 393. 
toda la capacidad crítica ${ }^{126}$ y de limitación que poseen cuando se reputan principios autónomos y, más aún, cuando se derivan de la propia Constitución.

Ahora bien, aun cuando la proporcionalidad no deriva de la prevención general, no cabe duda de que una y otra se encuentran vinculadas ${ }^{127}$. Y es que la experiencia ha demostrado que las penas más graves no son las más eficaces para obtener los objetivos prevencionistas, sino que las más eficaces son aquellas que resultan más adecuadas a la gravedad de los comportamientos, de manera que la pena proporcionada a la gravedad del hecho será también la más adecuada a la finalidad de tutela ${ }^{128}$. Así lo ha puesto de relieve, en parte, el propio Tribunal Constitucional en el FJ 6 de la Sentencia 55/1996, y lo ha reiterado en el FJ 9 de la Sentencia 161/1997, al afirmar: «Estos efectos (prevención general y especial) de la pena dependen a su vez de factores tales como la gravedad del comportamiento que se pretende disuadir, las posibilidades fácticas de su detección y sanción y las percepciones sociales relativas a la adecuación entre delito y pena ${ }^{129}$.

Pero tampoco cabe desconocer que, en algunos casos, la prevención y la proporcionalidad se hallan en conflicto: lo normal es que la gravedad de la pena no sea determinante de la eficacia preventiva, de forma que se favorece la coincidencia entre el interés de la proporcionalidad con el hecho y el de la intimidación, pero en otros casos el incremento de la pena por motivos de prevención, contrarios a la proporcionalidad en sentido estricto, desarrolla un efecto intimidatorio superior ${ }^{130}$. Desde nuestro punto de vista, existe una tendencia exagerada del legislador penal de intentar incrementar la eficacia preventiva del Derecho penal a través del aumento de las penas, que lleva a la merma de las garantías propias de un Estado de Derecho, entre las que se encuentra la proporcionalidad en sentido estricto.

Cuando se controla el respeto de la proporcionalidad en sentido estricto por parte del legislador se trata de contrapesar: por una parte, el menoscabo de derechos fundamentales que implica toda amenaza penal; $y$, por otra, la mejora que a través de la misma se consigue para la protección del bien jurídico ${ }^{131}$. En definitiva, si se produce un sacrificio excesivo del

126 Vid. la crítica formulada por SILVA SÁNCHEZ, Aproximación al Derecho..., cit., p. 235.

127 OCTAVIO DE TOLEDO, Sobre el concepto..., cit., p. 368.

128 COBO/VIVES, Derecho penal..., cit., p. 80.

129 En este sentido se ha manifestado un gran número de autores entre ellos, BECCARIA, De los delitos y de las penas..., cit., pp. 103 y 105»; PÉREZ MANZANO, Culpabilidad y prevención..., cit., p. 229; OCTAVIO DE TOLEDO, Sobre el concepto..., cit., p. 368 .

130 SILVA SÁNCHEZ, Aproximación al Derecho..., cit., p. 279.

131 VOGEL, «Strafrechtsgüter und Rechtsgüterschutz durch Strafrecht im Spiegel der Rechtssprechung des Bundesverfassungsgerichts», StV, 2/96, p. 114. Y así parece que lo entiende también nuestro Tribunal Constitucional cuando en la STC de 2 de octubre de 1997 afirma: «En aplicación de las ideas fundamentales relativas al principio de proporcionalidad como criterio de enjuiciamiento del tratamiento de derechos fundamentales, hemos de reiterar que la relación final que guarde la magnitud de los beneficios obtenidos por la norma penal y la magnitud de pena...» 
derecho fundamental que la pena restringe y por ello cabe esperar que el Tribunal Constitucional puede llevar a cabo un control más intenso en esta sede ${ }^{132}$.

\section{Excurso: relación entre principio de proporcionalidad en sentido estricto y el principio de culpabilidad}

El principio de proporcionalidad se distingue del principio de culpabilidad ya que el primero afecta al injusto del hecho y el segundo a la atribuibilidad del hecho. En el momento de decidir sobre la proporcionalidad abstracta se trata de exigir proporcionalidad entre la gravedad del injusto y la de la pena con la que se le sanciona, y no se trata de exigir la atribuibilidad del injusto ${ }^{133}$. Además, el principio de culpabilidad se encuentra desvinculado de la finalidad ${ }^{134}$. Como acertadamente afirma MIR PUIG, el principio de culpabilidad, entendido en sus justos términos, no es suficiente para garantizar la necesaria proporcionalidad entre delito y pena. La culpabilidad nada dice acerca de la gravedad del injusto ni, por tanto, que la pena deba adecuarse a la misma ${ }^{135}$. Por consiguiente, en el momento legislativo, el principio de proporcionalidad y el de culpabilidad se pueden distinguir con cierta facilidad y se complementan. Por este motivo se rechaza la propuesta de aquellos autores que han defendido la sustitución del principio de culpabilidad por el de proporcionalidad ${ }^{136}$.

\section{Proporcionalidad concreta}

El otro ámbito en el que opera el principio de proporcionalidad en sentido estricto es el de aplicación por parte del Juez de la pena concreta al autor, hablándose en estos casos de proporcionalidad concreta: la pena aplicada al autor por el Juez ha de ser proporcionada a la gravedad del hecho cometido. Puesto que los principios de culpabilidad y proporcionalidad en sentido estricto son condensadores de algunos de los principios constitucionales del sistema penal en relación con un individuo concreto, en el momento judicial la relación de complementación entre ambos conceptos se intensifica y, por ello, en el momento de imponer la pena concreta al autor, el juez deberá atender tanto a la gravedad del injusto como

132 VOGEL, «Strafrecthsgüter und Rechtsgüterschutz...», StV, 2/96, p. 113.

133 MIR PUIG, Introducción a las bases..., cit., p. 158; OCTAVIO DE TOLEDO, Sobre el concepto..., cit., p. 367; GARCÍA-PABLOS, Derecho penal, Introducción, cit., p. 290. En la primera sentencia en la que el Tribunal Constitucional se pronunció sobre el principio de proporcionalidad (STC 65/1986), se señala que los criterios que utiliza el legislador al establecer en abstracto y con carácter general las penas correspondientes a las diversas conductas tipificadas como delitos, nada tienen que ver con la culpabilidad del autor concreto.

134 ZIPF, Introducción a la política criminal, Madrid, 1979, p. 56.

135 MIR PUIG, Derecho penal..., cit., p. 100.

136 Sobre esta propuesta, cfr. AGUADO CORREA, El principio constitucional..., cit., p. 256 y ss. 
a la culpabilidad concreta ${ }^{137}$. El grado del injusto y el de la culpabilidad no tienen por qué coincidir, de forma que en un hecho de elevada gravedad la culpabilidad puede ser escasa, y viceversa. Por consiguiente, siguiendo el método ofrecido por la teoría del delito, el juez tendrá que examinar en primer lugar la gravedad del injusto (principio de proporcionalidad) y en segundo lugar debe valorar en qué medida es atribuible a su autor (principio de culpabilidad $)^{138}$.

Por último, destacar que el principio de proporcionalidad en sentido estricto, entendido como un principio constitucional que limita la prevención, se opone a ser vulnerado hacia arriba, pero no hacia abajo, es decir, constituye un límite máximo y no un límite mínimo ${ }^{139}$. El principio de proporcionalidad no impide que pueda disminuirse o incluso renunciarse a la pena por razones de prevención especial y, más concretamente, para impedir la desocialización o facilitar la socialización ${ }^{140}$. En estos casos en los que la finalidad de tutela de la pena puede quedar satisfecha bien con una pena menor o bien incluso sin pena alguna, «la proporcionalidad ha de ser entendida conforme a los requerimientos de la finalidad de tutela, que es el único objeto de ponderación, y no según la gravedad del, que es sólo un criterio genérico para efectuarla ${ }^{141}$. En este sentido es en el que vendría a confluir la proporcionalidad en sentido estricto con la necesidad ${ }^{142}$.Por todo lo expuesto hasta ahora, y ante la insuficiencia del mecanismo previsto para asegurar la proporcionalidad concreta de una determinada pena, sería deseable, desde nuestro punto de vista, que se previese la posibilidad de que el Juez o Tribunal prescinda de la pena cuando resulte desproporcionada o innecesaria ${ }^{143}$.

137 En este sentido también se ha pronunciado ZIPF, Introducción a la política criminal, cit., p. 56. El Tribunal Constitucional, en la Sentencia de 22 de mayo de 1986 (FJ 3), afirma que la cuestión de la desproporción de la pena en el momento de su individualización se plantea en aquellos casos en los que la gravedad de la pena atribuida al condenado fuese superior a la legalmente imponible en relación a la gravedad de su culpabilidad.

138 MIR PUIG, Introducción a las bases..., cit., p. 164. Como señala este mismo autor, «Sobre el principio de culpabilidad como límite de la pena», en El Derecho penal en el Estado social y democrático de Derecho, Barcelona, 1994, pp. 178 y 179, el principio de culpabilidad no debe confundirse con la exigencia de cierta proporción entre la pena y la gravedad del delito, al no existir en nuestra legislación un precepto con el § 46 StGB en el que la imposición de la pena al individuo se fundamenta explícitamente en la culpabilidad del sujeto.

139 MIR PUIG, Introducción a las bases..., cit., pp. 104 y 105. Ésta es una de las diferencias que existen entre la postura sostenida por los defensores de la prevención general positiva fundamentadora y la que aquí sostenemos. Para aquéllos, no es posible imponer penas inferiores a lo «proporcionado» por los posibles efectos desestabilizadores que ello podría conllevar; cfr. SILVA SÁNCHEZ, Aproximación al Derecho..., cit., p. 259.

140 SILVA SÁNCHEZ, Aproximación al Derecho..., cit., p. 297.

141 COBO/VIVES, Derecho penal..., cit., pp. 80 y 81.

142 COBO/VIVES, Derecho penal..., cit., p. 81.

143 En este sentido también se pronuncia QUINTERO OLIVARES, Curso de Derecho..., cit., p. 542, para quien el marco penal debería incluir, junto al límite mínimo, la posibilidad de no imponer pena alguna para los casos de desproporción o falta de sentido. 


\section{Delitos de peligro abstracto}

\section{V.1. Delimitación conceptual de los delitos de peligro abstracto}

La ley tan sólo contiene tipos delictivos, no contiene ni delitos de lesión ni delitos de peligro, procediendo su distinción por parte de la doctrina de su puesta en relación con los bienes jurídicos protegidos ${ }^{144}$. Si bien la mayoría de la doctrina lleva a cabo esta distinción acudiendo al criterio de la intensidad del ataque al bien jurídico ${ }^{145}$, no obstante, hay autores que distinguen los delitos de lesión de los delitos de peligro (concreto) según la intensidad del menoscabo del objeto de la acción ${ }^{146}$.

Dentro de los delitos de peligro es usual la distinción entre delitos de peligro abstracto y delitos de peligro concreto e incluso, algunos autores reconocen una tercera categoría denominada delitos de peligro abstracto-concreto. Los delitos de peligro concreto se diferencian en esencia de los delitos de lesión, no en virtud de los distintos criterios de imputación, sino que en vez de un resultado de lesión se da un resultado de peligro concreto. También hay autores que admiten la existencia de una categoría intermedia entre los delitos de peligro abstracto y los delitos de peligro concreto. La nomenclatura es variada y también varían las características y los delitos incluidos en esta categoría por parte de los distintos autores. En Alemania, SCHRÖDER habla de los delitos de peligro abstracto-concreto ${ }^{147}$, mientras que HOYER habla de delitos de aptitud ${ }^{148}$. Lo cierto es que esta postura no cuenta con muchos adeptos, señalando acertadamente la mayoría de la doctrina, tal y como en un principio hizo GALLAS ${ }^{149}$, que algunos de estos delitos que se han incluido en una categoría intermedia pueden ser considerados como delitos de peligro concreto, en tanto que la mayoría de ellos no son sino delitos de peligro abstracto.

Por lo que respecta a los delitos de peligro abstracto, es usual que la doctrina los defina de forma negativa a través de su confrontación con los delitos de peligro concreto y de

144 BOHNERT, «Die Abstraktheit der abstrakten Gefährdungsdelikte», JuS, 1984, p. 184.

145 La mayoría de la doctrina lleva a cabo la distinción entre delitos de lesión y de peligro atendiendo a la intensidad del ataque al bien jurídico, cfr. referencias doctrinales en AGUADO CORREA, El principio constitucional..., cit., p. 271, n.p.p. 14 .

146 Hay autores como JESCHECK, Tratado de Derecho penal, $4 .{ }^{\text {a }}$ ed., pp. 234 y ss., que distinguen entre delitos de lesión y delitos de peligro (concreto) según la intensidad del menoscabo del objeto de la acción; ROXIN, Strafrecht. Allgemeiner Teil, cit., § 10/122 (273); JAKOBS, Strafrecht. Allgemeiner Teil, Die Grundlagen und die Zurechnungslehre, 2. ${ }^{a}$ Auf., Berlin, 1991, § 6/78.

147 SCHRÖDER, «Abstrakt-konkrete Gefährdungsdelikte?», JZ1967, pp. 522 y ss. Esta denominación ya fue utilizada por HERRMANN, Zum Begriff der Gefahr, insbesondere der Gemeingefahr im deutschen Strafrecht, Düsseldorf, 1939, pp. 20 y ss.

148 HOYER, Die Eignungsdelikte, Berlín, 1987, passim. En esta categoría incluye este autor aquellos delitos en los que, sin exigirse un resultado, tampoco se renuncia de una forma completa a la referencia a la víctima en la norma.

149 GALLAS, en su artículo «Abstrakte und konkrete Gefährdung», en Festschrift für Heinitz, Berlín, 1972, p. 171, analiza la propuesta realizada en su día por SCHRÖDER. 
lesión, como aquellos en los que no se exige ni la puesta en peligro en concreto ni la lesión del bien jurídico protegido. Un exponente claro de esta tendencia a la configuración de los delitos de peligro abstracto de forma negativa, lo encontramos en la definición que ofrece HORN de los delitos de peligro abstracto: «El concepto de delitos de peligro abstracto tan sólo indica algo negativo: que el legislador no ha establecido como elemento del tipo ni la lesión ni la puesta en peligro concreto del bien jurídico protegido por la norma» ${ }^{150}$. Pero qué caracteriza positivamente a los delitos de peligro abstracto es una cuestión que está abierta y sin una respuesta única. Ello se debe, en parte, a que de la configuración legal de los delitos de peligro abstracto no se extrae ningún elemento común a todos ellos que haga posible el reconocimiento de cuándo estamos ante un delito de peligro abstracto, y más aún, si tenemos en cuenta que no todos los tipos recogen expresamente los bienes protegidos por los mismos ${ }^{151}$.

Si nos preguntamos por la justificación de la denominación de estos delitos como delitos de peligro abstracto, así como por el motivo de su incriminación, podemos encontrar dos posturas que intentan dar respuesta a esta cuestión y que ya fueron recogidas por BIN$D_{I N G}{ }^{152}$ : la teoría de la peligrosidad general o teoría de la peligrosidad o del peligro como motivo y, por otra parte, la teoría de la peligrosidad abstracta o teoría de la presunción ${ }^{153}$. Común a ambas teorías es la absoluta falta de referencia al peligro en el caso concreto, ignorándose por completo los problemas que plantean aquellos supuestos en los que, a pesar de haberse realizado la acción generalmente peligrosa, no se origina peligro alguno para el bien jurídico protegido debido a la concurrencia de determinadas circunstancias. Y es esta falta de referencia al caso concreto la que ha originado las más intensas críticas de la doctrina a la categoría de los delitos de peligro abstracto, y la que hace necesario replantearse la misma teniendo en cuenta los principios constitucionales que afectan al Derecho penal.

150 HORN, en Systematischer Kommentar..., cit., vor § 306, Nm. 15. También GRAUL, Abstrakte Gefährdungsdelikte und Präsumtionen im Strafrecht, Berlin, 1991, pp. 108 y 109, da una definición casi coincidente de delitos de peligro abstracto, si bien se diferencia de la ofrecida por HORN, como ella misma pone de manifiesto, p. 141, en que este autor concede un carácter meramente negativo a esta definición; por contra, ella, en tanto que en los delitos de peligro abstracto se trata de proteger bienes jurídicos, ve un factor (concepto) positivo determinante.

151 Si consideramos, como hace la mayoría de la doctrina, que los denominados delitos de aptitud son delitos de peligro abstracto, en estos casos sí que en el tipo se hace referencia expresa a los bienes jurídicos protegidos.

152 BINDING, Die Normen und ihre Übertretung I, $2 .^{\mathrm{a}}, 1890$, pp. 379 y 380.

153 Cfr. sobre los postulados de estas teorías y sus partidarios, AGUADO CORREA, El principio constitucional..., cit., pp. . 273 y ss. 


\section{V.2. Compatibilidad de los delitos de peligro abstracto con el principio de proporcionalidad en sentido amplio}

En las páginas que siguen nos vamos a ocupar del respeto por parte de los delitos de peligro abstracto del principio constitucional de proporcionalidad en sentido amplio. Una vez que hemos constatado que nos encontramos ante un principio constitucional que limita el ius puniendi consagrado en los artículos 1.1, 9.3 y 10.1 CP, que tiene una especial virtualidad y se aplica normalmente en el ámbito de los derechos fundamentales, y que en el Derecho penal consideramos que se descompone en el principio de aptitud, en el de necesidad, que a su vez se concreta en el de protección exclusiva de bienes jurídicos y en el de intervención mínima y, en último lugar, en el principio de proporcionalidad en sentido estricto, pasamos a estudiar si la técnica utilizada en los denominados delitos de peligro abstracto vulnera alguno o algunos de estos principios.

El principal problema que plantean los denominados delitos de peligro abstracto se debe, fundamentalmente, a la amplitud con la que son redactados por el legislador. Por una parte, en el tipo se incluyen aquellas acciones que pese a ser subsumibles formalmente en el comportamiento descrito por la norma, en el caso concreto no son idóneas para menoscabar el bien jurídico protegido. Esta realidad y los problemas que de ella se derivan ha sido ampliamente discutida por la doctrina, tanto española como extranjera, y se han buscado distintas soluciones dogmáticas. Además, la importancia de este problema se debe a que no sólo posee dimensiones dogmáticas, sino que también adquiere dimensiones constitucionales, siempre que se pongan en relación estos delitos con el principio de exclusiva protección de bienes jurídicos y con el principio de ofensividad, los cuales, como ya hemos visto, forman parte del principio de proporcionalidad en sentido amplio.

Sin embargo, no se acaban en la compatibilidad de los delitos de peligro abstracto con el principio de exclusiva protección de bienes jurídicos y de ofensividad, los problemas con relevancia constitucional que plantean, desde nuestro punto de vista, aquéllos. Los supuestos en los que se pone en peligro el bien jurídico de manera insignificante pueden plantear problemas puestos en relación con el principio constitucional de proporcionalidad en sentido estricto. Se debe a que los delitos contra bienes jurídicos supraindividuales se suelen configurar como delitos de peligro abstracto, no exigiéndose, pues, ni la lesión ni la puesta en peligro concreto del bien jurídico en cuestión, debido a la imposibilidad de su comprobación. Como señalan algunos autores, el medio para una protección jurídico-penal eficaz de los bienes jurídicos supraindividuales y los objetos de ataque, en cuanto objetos 
Principio de proporcionalidad y delitos de peligro abstracto

TERESA AGUADO-CORREA

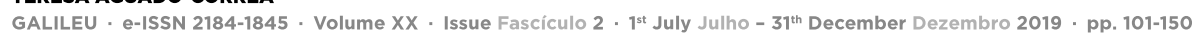


ideales, consistiría en los delitos de peligro abstracto ${ }^{154}$, con el «peligro» que ello conlleva de ampliar demasiado el ámbito del Derecho penal a comportamientos en los que falta el merecimiento o la necesidad de pena, o en los que, dándose ambos requisitos, falta la necesaria proporción entre la entidad del delito y la entidad de la pena.

En el estudio que realizamos a continuación, lo que pretendemos poner de relieve es hasta qué punto el principio de proporcionalidad en sentido amplio se comporta como un verdadero límite al ius puniendi ${ }^{155} \mathrm{y}$ hasta qué punto, en caso de que no sea respetado por el legislador cuando utiliza la técnica del peligro abstracto, puede ser objeto de control por parte del Tribunal Constitucional su vulneración, puesto que nos encontramos ante un principio constitucional. No tratamos de pronunciarnos sobre la vulneración o no de este principio por parte del legislador cada vez que utiliza a lo largo del Código Penal esta técnica, sino de realizar una serie de consideraciones generales. Somos conscientes de que cualquier intento de dar una solución global y válida sobre la legitimación y validez de todos los delitos de peligro abstracto está abocada al fracaso y se requiere un estudio detallado de cada grupo de delitos, pero ello excede de las pretensiones de nuestro trabajo.

\section{V.2. A. Principio de idoneidad y delitos de peligro abstracto}

\section{Idoneidad de los delitos de peligro abstracto para la protección de bienes jurídicos.}

Los delitos de peligro abstracto encuentran su justificación en la necesidad de una tutela más acabada y eficaz de los bienes jurídicos que se consideran esenciales y, fundamentalmente, de los denominados bienes jurídicos colectivos ${ }^{156}$. Sin embargo, como ya dijimos cuando tratamos el principio idoneidad del Derecho penal, no todos los bienes jurídicos son aptos o idóneos para ser protegidos penalmente. De ello podemos concluir que no serán idóneos para proteger bienes jurídicos aquellos delitos de peligro abstracto que consisten en la violación de reglas ético-sociales o ético-religiosas, al no tipificar acciones que supongan peligro alguno para un bien digno de protección jurídico-penal157.

154 OTTO, Grundkurs Strafrecht. Die einzelnen Delikte, $4 .^{\text {a }}$ ed., Berlín 1995, p. 283; TIEDEMANN, Wirtschaftsstrafrecht und Wirtschaftskriminalität, Band 1, Hamburg, 1976, pp. 41 y ss.

155 En este análisis tendremos muy presente lo afirmado por el Tribunal Constitucional alemán en la Sentencia de 9 de marzo de 1994 (BVerfGE 90, 145), conocida popularmente como la sentencia del cannabis o del hashish. En ella se pronunció sobre la posible vulneración del principio de proporcionalidad por parte de los preceptos de la Betäubungsmittelgesetz (BtMG), que amenazan con pena el tráfico ilegal de drogas o la posesión de las mismas cuando se trata de productos derivados del cannabis; preceptos, en los que el legislador había acudido a la técnica del peligro abstracto..

156 MAQUEDA ABREU, «La idea de peligro en el moderno Derecho penal. Algunas reflexiones a propósito del Proyecto de Código Penal de 1992», Actualidad Penal, 1994, p. 487.

157 En este sentido FIANDACA, «La tipizzazione del pericolo», Dei Delitti e delle Pene, 1984, p. 460, cuestiona la admisibilidad constitucional y político-criminal de la protección a través de la técnica de los delitos de 
Por otra parte, se puede afirmar que un tipo penal es apto para la protección de un bien jurídico siempre y cuando las acciones típicas por él descritas afecten de algún modo al bien jurídico. De ello se deduce que aquel tipo penal en el que se tipifique acciones que de ningún modo afectan al bien jurídico que se pretende proteger a través del mismo, será inidóneo, puesto que la protección del bien jurídico no puede tener lugar a través de dicha prohibición. Al ser inidóneo para la protección del bien jurídico, dicho tipo se puede considerar inconstitucional por ser contrario al principio de proporcionalidad en sentido amplio. Por lo tanto, no son idóneos los delitos de peligro abstracto para la protección del bien jurídico cuando a través de los mismos se incriminan meras infracciones administrativas que no suponen peligro alguno para el respectivo bien jurídico ${ }^{158}$. Lo más inquietante es que este problema, la criminalización de meros injustos administrativos, está adquiriendo de nuevo importancia en los ordenamientos jurídicos.

Pero no podemos desconocer que en los casos en los que el bien jurídico puede ser afectado a través de una gran variedad de conductas, a veces es difícil establecer una línea de separación entre las conductas inofensivas y aquellas otras conductas que afectan al bien jurídico. Y es en los denominados delitos de peligro abstracto, a través de los cuales se incriminan aquellas acciones general y abstractamente peligrosas para el bien jurídico, donde resulta bastante difícil para el legislador separar claramente a la hora de tipificar, aquellos comportamientos inofensivos de los que realmente suponen un peligro abstracto para el bien jurídico protegido. En aquellos supuestos en los que encuentra dificultades para esta delimitación, y debido a la importancia del bien jurídico en juego, el legislador considera más idóneo para su protección acudir a la prohibición de un comportamiento generalmente peligroso para el bien jurídico, sin que de esta manera se privilegien los comportamientos menos peligrosos. Desde el punto de vista de la idoneidad, no hay nada que objetar a esta forma de tipificación siempre que se trate de un comportamiento generalmente peligroso, no estando justificada, por el contrario, la conminación penal de comportamientos que excepcionalmente pueden resultar peligrosos para el bien jurídico. Queda justificada, por este motivo, la idoneidad de esta técnica en el delito de tráfico de drogas o en el supuesto del delito de conducción bajo la influencia de bebidas alcohólicas, drogas tóxicas o estupefacientes.

En el seno de la doctrina, un considerable número de autores afirma que la utilización de la técnica de los delitos de peligro abstracto es la más idónea/eficaz para protección de

peligro abstracto de objetos tales como el pudor público. TORÍO LÓPEZ, «Los delitos del peligro hipotético (Contribución al estudio diferencial de los delitos de peligro abstracto)», ADPCP, 1981, pp. 827 y ss., distingue tres grupos de delitos de peligro abstracto, estando los primeros constituidos por los delitos que consisten en la violación de reglas ético-sociales o ético-religiosas.

158 Es el segundo grupo de delitos dentro de los de peligro abstracto que distingue TORÍO LÓPEZ. 
los bienes jurídicos colectivos ${ }^{159}$, aun cuando también hay quien se plantea hasta qué punto es correcto en estos casos hablar de delitos de peligro ${ }^{160}$ y quien considera preferible para su protección la configuración del delito como de lesión o incluso de peligro concreto ${ }^{161}$.

Lo cierto es que la opción adoptada por el legislador cuando se trata de proteger bienes jurídicos colectivos es la técnica del peligro abstracto, ya que suele acudir a la prohibición de acciones generalmente peligrosas para los bienes jurídicos fundamentalmente para evitar los problemas de prueba que se plantearían si se exigiese la puesta en peligro concreto o la lesión de estos bienes jurídicos colectivos ${ }^{162}$. Se trata de ámbitos en los que es muy difícil tipificar la producción de resultados lesivos o de puesta en peligro concreto, al exigir los delitos de resultado el conocimiento y comprobación del nexo causal entre la acción individual y el resultado, siendo más fácil la determinación de la aptitud general de determinados comportamientos para poner en peligro el bien jurídico protegido ${ }^{163}$.

Por otra parte, normalmente la prohibición de las conductas que pongan en peligro o lesionen el bien jurídico no es suficiente para su protección, ya que en general los ataques a estos bienes jurídicos tienen lugar a través de acciones masas cuya peligrosidad indivi-

159 Con carácter general consideran que los delitos de peligro abstracto son los más eficaces para la protección de los bienes jurídicos colectivos, entre otros, FIANDACA, «La tipizzazione del pericolo», Dei Delliti e delle Pene, 1984, pp. 454 y ss; MUÑOZ CONDE, «El "moderno" Derecho penal en el nuevo Código Penal, principios y tendencias», La Ley, 1996, p. 1340; VALLE MUÑIZ, en Comentarios al nuevo..., cit., p. 1329. Por el contrario, MÉNDEZ RODRÍGUEZ, Los delitos de peligro y sus técnicas de tipificación, Madrid, 1993, pp. 160 y 161, afirma que es erróneo estimar que lo más eficaz para la protección de los bienes jurídicos colectivos es la creación de delitos de peligro abstracto porque la lesión no es determinable. Sobre los autores que consideran que en el ámbito del Derecho penal económico que la técnica de protección más idónea es la del peligro abstracto, debido al carácter ideal tanto del bien jurídico como del objeto de ataque, vid. AGUADO CORREA, El principio constitucional..., cit., p. 283, n.p.p. 66.

160 TIEDEMANN, Poder económico y delito..., cit., p. 36; MAQUEDA ABREU, «La idea de peligro...», Actualidad Penal, núm. 26 (1994), p. 492; GARCÍA RIVAS, Contribución al estudio de peligro y aplicación a los delitos contra la salud pública y el medio ambiente, Albacete, 1995, p. 148; TERRADILLOS BASOCO, Derecho penal de la empresa, Madrid, 1995, p. 57.

161 En este sentido se manifiestan BUSTOS RAMÍREZ, «Los bienes jurídicos colectivos», RFDUCM, núm. 11 (1986), p. 160; MÉNDEZ RODRÍGUEZ, Los delitos de peligro..., cit., p. 161; TERRADILLOS BASOCO, Derecho penal de la empresa, cit., p. 57.

162 WEBER, «Die Vorverlegung des Strafrechtsschutzes durch Gefährdungs - und Unternehmensdelikte», ZStW, Beiheft, 1987, pp. 24 y ss. WEIGEND, «Bewältigung von Beweisschwierigkeiten...?, Festschrift für Otto Triffterer, 1996, p. 695 y ss., sostiene que el legislador penal tiene varias formas de evitar las dificultades de prueba que se le puedan presentar, soluciones que redundan en una ampliación material del Derecho penal. En el XIII Congreso de la Asociación Internacional de Derecho Penal sobre «El concepto y los principios fundamentales del Derecho penal económico y de la empresa» (El Cairo, 1984) se admite la validez de los delitos de peligro abstracto para la lucha contra la delincuencia económica y de la empresa, siempre que la conducta que se prohíbe se determine con claridad y los bienes jurídicos también se encuentren determinados. Por contra, niegan la justificación de los delitos de peligro abstracto cuando exclusivamente se pretenda facilitar la prueba de los delitos.

163 Como acertadamente pone de manifiesto TERRADILLOS BASOCO, «Protección penal del medio ambiente en el nuevo Código Penal español. Luces y sombras», Estudios Penales y Criminológicos, XIX (1996), p. 317, el argumento de la dificultad de la imputación objetiva del resultado presente en el origen de la mayoría de los delitos de peligro abstracto y que exonera al juez de la obligación de verificar la corrección del juicio de peligro elaborado por el legislador en el tipo, se puede replicar afirmando que mayores son las dificultades con las que topa el legislador que tiene que actuar sobre supuestos más generales. 
dualmente considerada es insignificante, pero cuya repetición puede menoscabar el bien jurídico. Es lo que sucede, por ejemplo, en los delitos contra el medio ambiente ${ }^{164}$, en los que resulta particularmente difícil especificar tanto cuantitativa como cualitativamente los efectos que una conducta particular ocasiona sobre el medio ambiente y en los que la afectación del bien jurídico tiene lugar por la repetición generalizada y frecuente de la conducta $^{165}$. Con el mismo problema que en los delitos contra el medio ambiente se encuentra el legislador, según un sector de la doctrina, cuando se trata de tipificar los ataques a los bienes jurídicos colectivos que se refieren a estructuras o instituciones básicas en el funcionamiento del Estado o del sistema social (contra la Administración de Justicia, contra la Administración Pública, contra el orden socio-económico): la tipificación de una lesión o un peligro concreto es difícil porque el menoscabo del bien jurídico se produce por la reiteración generalizada de conductas que no respetan las reglas básicas que permiten asegurar el sistema y su funcionamiento, más que por una conducta concreta ${ }^{166}$. Y para soslayar este problema, el legislador decide acudir a la técnica de tutela que considera más eficaz: los delitos de peligro abstracto. Parte de la doctrina habla en estos casos de «delitos con bien jurídico intermedio espiritualizado», adoptando la denominación propuesta por SCHÜNE$\mathrm{MANN}^{167}$, quien incluía en esta categoría delitos en los que se sostiene que la lesión del bien jurídico intermedio representa, por sí misma, un injusto ${ }^{168}$.

164 Cfr. AGUADO CORREA, El principio constitucional..., cit., p. 286, n.p.p. 71, sobre el gran número de autores que consideran preferible la tipificación como delito de peligro abstracto en materia medio ambiental. Contrario a la utilización de tipos de peligro en materia medio-ambiental se muestra PRATS CANUT en Comentarios al Nuevo..., cit., pp. 1518 y 1519

165 KLEINE-COSACK, Kausalitätsprobleme im Umweltstrafrecht, Berlín, 1988, pp. 77 y 78.

166 En este sentido LOOS, «Zum "Rechtsgut" der Bestechungsdelikte», Festschrift für Welzel, 1974, 879 y ss.; ANGIONI, Contenuto e funzioni..., cit., pp. 63 y ss.; FIANDACA, «La tipizzazione del pericolo», Dei Delitti e delle Pene, 1984, 456; GRASSHOF, BVerfGE 90, 145 (204), y en el seno de nuestra doctrina RODRÍGUEZ MONTAÑ́́S, Delitos de peligro..., cit., p. 301.

167 Este autor («Moderne Tendenzen in der Dogmatik der Fahrlässigkeits - und Gefährdungsdelikte», JA, 1975, p. 798) distingue tres categorías dentro de los delitos de peligro abstracto. La primera de ellas viene constituida por los «delitos con bien jurídico intermedio espiritualizado» («Delikte mit einem vergeistigten Zwischenrechtsgut»); la segunda, por las acciones masas, y la tercera, por aquellos delitos en los que se tipifica una tentativa imprudente que se caracteriza por la «infracción del cuidado subjetivo». Esto ocurriría, según este autor, en delitos tales como el falso testimonio, el cohecho y el delito de falsedad documental, aun cuando en la doctrina es más discutida la consideración de este último como un delito de peligro abstracto. Entre otros, han adoptado esta denominación WOLTER, Objektive und personale Zurechnung von Verhalten, Gefahr und Verletzung in einem funktionalen Strafrechtssystem, Berlin, 1981, pp. 328 y ss.; ROXIN, Strafrecht. Allgemeiner Teil, cit., 11/126; RODRÍGUEZ MONTAÑÉS, Delitos de peligro, dolo e imprudencia, Madrid, 1994, p. 300. JAKOBS, Strafrecht. Allgemeiner Teil, cit., 6/88, si bien no utiliza esta denominación, llega a la misma conclusión que SCHÜNEMANN, según señala el propio autor, de que cuando un delito es de peligro abstracto ello no impide que su resultado lesione un objeto que representa al bien en un plano menos abstracto.

168 ROXIN, Strafrecht. Allgemeiner Teil, cit., § 11/126, considera que el desvalor de la acción en estos delitos fundamenta por sí solo la punibilidad, puesto que el bien jurídico correspondiente no ha de ser puesto en peligro en el caso concreto a través de la acción subsumible en el tipo. 
En el seno de la doctrina española sostiene que la técnica del peligro abstracto es la más idónea para proteger los «delitos con bien jurídico intermedio con función representativa», siguiendo las propuestas de los autores alemanes, RODRÍGUEZ MONTAÑ́́S ${ }^{169}$. Para esta autora, esta técnica estaría justificada siempre y cuando el bien que se trata de proteger tenga la suficiente entidad para ser merecedor de tutela penal, pues aquí no se trata de anticipar la protección de bienes jurídicos esenciales. Dentro de esta categoría incluye delitos tales como el falso testimonio ${ }^{170}$, el cohecho pasivo, malversación de caudales públicos, tráfico de influencias... ${ }^{171}$. Asimismo, esta autora sostiene que estas consideraciones sobre los «delitos con bien jurídico intermedio con función representativa» son extensibles a los delitos contra el medio ambiente, en el caso de que se configuren como delitos de peligro abstracto, o bien a los delitos monetarios o a los delitos contra la Hacienda Pública, delitos a través de los cuales se protegen mediatamente estructuras básicas de la vida económica ${ }^{172}$.

Si bien no discutimos que entre los delitos incluidos en la categoría de los denominados delitos «con bien jurídico espiritualizado» existen verdaderos delitos de peligro abstracto, no creemos que todos los que incluye esta autora en esta categoría quepa considerarlos como delitos de peligro abstracto, tal y como sucede, por ejemplo, con el delito de cohecho pasivo propio ${ }^{173}$. No creemos que, tal y como afirma RODRÍGUEZ MONTAÑÉS, el injusto de

169 RODRÍGUEZ MONTAÑÉS, Delitos de peligro..., cit., pp. 300 y ss. Para esta autora, a través de estos delitos se están protegiendo «bienes jurídicos supraindividuales de carácter inmaterial a través de bienes u objetos intermedios con una función representativa, en cuya lesión reiterada y generalizada radica la "abstracta peligrosidad" de la conducta típica, sin que ello tenga relevancia directa ni en el tipo objetivo ni en el tipo subjetivo». Y por ello se considera que la vía idónea para la protección de estos bienes jurídicos es la técnica del peligro abstracto. Esta autora tan sólo admite la atipicidad de la conducta cuando se trate de «ataques mínimos», en virtud del principio de insignificancia. Como ella misma reconoce, los autores alemanes que admiten esta categoría de delitos de peligro abstracto también admiten como único correctivo típico los «ataques mínimos», pero sin hacer mención al principio de insignificancia. No comparte la división que propone esta autora entre bienes jurídicos individuales o individualizables y bienes jurídicos supraindividuales o institucionalizados $\mathrm{MUÑOZ}$ CONDE, en HASSEMER/MUÑOZ CONDE, La responsabilidad por el producto en Derecho penal, Valencia, 1995, p. 60, para quien en última instancia la razón de éstos es la protección de bienes jurídicos individuales.

170 Para esta autora (Delitos de peligro..., cit., p. 302), el bien jurídico institucionalizado mediatamente protegido o «representado» por este delito, tal y como venía configurado en el CP anterior (arts. 326 y ss.), regulación que en lo básico coincide con la del CP 1995, es la correcta Administración de Justicia. Además, afirma que el tipo se conforma con la lesión de «la veracidad de las declaraciones procesales» («objeto representativo»).

171 En todos estos delitos el bien jurídico inmaterial mediatamente protegido, en opinión de RODRÍGUEZ MONTAÑÉS, Delitos de peligro..., cit., p. 303, es el correcto funcionamiento de la Administración pública. Sostiene, además, que este bien jurídico no es susceptible de ser menoscabado a través de conductas individualmente consideradas, pero sí si se repiten y generalizan.

172 RODRÍGUEZ MONTANEÉS, Delitos depeligro.., cit.,pp. 303 y 304,n.p.p. 347, considera que si bien el incumplimiento de los deberes tributarios no supone individualmente una lesión o puesta en peligro de la economía estatal, ello podría tener lugar a través de la generalización y repetición de tales conductas.

173 Si consideramos, como acertadamente hace VALEIJE ÁLVAREZ, «Consideraciones sobre el bien jurídico protegido en el delito de cohecho», EPC, XVIII (1995), p. 354, que nociones como la de «buen funcionamiento», «pureza» o «prestigio» no satisfacen los aspectos fundamentales que el concepto de bien jurídico exige al ordenamiento jurídico y que el bien jurídico protegido en el delito de cohecho pasivo es el principio de imparcialidad de la actuación administrativa entendido como medio para alcanzar una satisfacción igual y 
estos delitos pueda basarse en la mera infracción de deberes y que se niegue toda referencia al bien jurídico que de forma «mediata» se protege y que, según esta autora, es merecedor de tutela penal. En estos delitos no hay más que un bien jurídico y la antijuricidad material de todo delito se construye en base al mismo. Por otro lado, el que parte de la doctrina considere que la forma más idónea de proteger determinados bienes jurídicos es la técnica de peligro abstracto no quiere decir que el legislador haya hecho uso de esta técnica para protegerlos, pudiendo haber configurado un delito de lesión o de peligro concreto. Creemos que esta autora no ha tenido en cuenta que en cada uno de los delitos que enumera se protege un bien jurídico más concreto que el del correcto funcionamiento de la Administración Pública, en cuya lesión o puesta en peligro concreto se agota el injusto material del delito. Hay determinados supuestos en los que se pueden identificar bienes jurídicos intermedios que gozan de autonomía propia, a pesar de ser instrumentales respecto de los bienes jurídicos representados ${ }^{174}$. Tampoco hay que confundir, como ya pusimos de manifiesto, el bien jurídico protegido con la ratio legis. Puede ser que el legislador a través de estas incriminaciones pretenda el correcto funcionamiento de la Administración Pública, pero no por ello ha de erigirse éste directamente en bien jurídico. El bien jurídico ha de ser lesionado o puesto en peligro; la finalidad perseguida por el legislador, sin embargo, no tiene por qué cumplirse. Por otra parte, en la reiteración generalizada no puede residir la abstracta peligrosidad de la acción, puesto que si ello fuese así se estaría culpando al autor por las demás acciones que contribuyen a la puesta en peligro abstracto del bien jurídico y no por su acción. Otro de los ámbitos en los que ha sido tradicional el uso por parte del legislador de la técnica de los delitos de peligro, y más concretamente de la técnica de los delitos de peligro hipotético y de peligro abstracto en sentido tradicional, es el ámbito de los delitos contra la salud pública. Sobre el bien jurídico protegido en estos delitos se ha escrito mucho en nuestro país, y en este momento no nos interesa reproducir la polémica doctrinal que sobre el mismo ha existido, pero sí diremos que consideramos que la salud pública es un bien jurídico colectivo merecedor, necesitado y capaz de protección penal, y que posee autonomía frente al bien jurídico salud individual, sin perjuicio de que uno de los bienes jurídicos individuales sea mediatamente protegido ${ }^{175}$.

objetiva de los intereses generales, cabría concluir que en el delito de cohecho pasivo propio (arts. 419, 420, 421) nos encontramos ante delitos de lesión.

174 TERRADILLOS, Derecho penal de la empresa, cit., p. 57.

175 En este sentido, HASSEMER/MUÑOZ CONDE, La responsabilidad por el producto..., cit., pp. 56 y 57; CORCOY BIDASOLO, «Resultado de muerte y lesiones como consecuencia de un delito contra la salud pública» (comentario a la STS de 22 de abril de 1987; ponente: Marino Barbero Santos), ADPCP, 1989, 337 y ss. GARCÍA ALBERO, en Comentarios al Nuevo..., cit., p. 1603.También hay un sector de la doctrina para el cual la salud pública no constituye un bien jurídico autónomo, sino que lo que se protege a través de estos tipos penales no es más que la salud individual de cada uno de los consumidores y del grupo social que todos ellos forman. En este 


\section{Control constitucional del respeto del principio de idoneidad}

El legislador cree que la técnica más idónea para la protección de determinados bienes jurídicos, y fundamentalmente de bienes jurídicos colectivos, es la utilización de la técnica de los delitos de peligro abstracto, valiéndose cada vez con más frecuencia de la técnica de los delitos de peligro hipotético en los que el legislador incluye elementos normativos de aptitud en el tipo, sin que por ello dejen de ser delitos de peligro abstracto, debiendo comprobar el juez en el caso concreto la aptitud lesiva de la conducta. En algunos supuestos, no compartimos la decisión adoptada por legislador: en unos casos porque creemos que hubiese sido más idóneo para la protección del bien jurídico correspondiente el uso de la técnica del delito de peligro hipotético en vez de la técnica del peligro concreto; en otros casos, no consideramos idónea la utilización de la técnica de los delitos de peligro abstracto por parte del legislador porque a través de los mismos se trata de incriminar meros injustos administrativos, meros incumplimientos de deberes en los que no estamos ante comportamientos generalmente peligrosos, sino que sólo excepcionalmente pueden resultar peligrosos para el bien jurídico.

No tiene sentido que nos planteemos aquí la idoneidad o no de todos y cada uno de los delitos que nuestro legislador ha configurado como delitos de peligro abstracto, porque en este trabajo queremos hacer hincapié en la virtualidad del principio de prohibición en sentido amplio como límite del ius puniendi y el control del cumplimiento de este principio constitucional. Lo cierto es que el legislador tiene un amplio ámbito de decisión en el momento de elegir el medio más idóneo para alcanzar el fin pretendido y el Tribunal Constitucional en el control de esta decisión muy poco tiene que decir.

Como muestra de lo que acabamos de afirmar sobre el ámbito de decisión del legislador, tenemos tanto el pronunciamiento del Tribunal Constitucional alemán sobre los preceptos de la BtMG como algún pronunciamiento de nuestro Tribunal Constitucional (SSTC 161/1997 y 136/1999). En Alemania, el juicio de aptitud no es un requisito difícil de cumplir, y ello no sólo por la prerrogativa de evaluación y espacio de decisión que se le concede al legislador penal, sino también debido a que el BVerfG únicamente reconoce la inconstitucionalidad de aquellas leyes que manifiestamente no son aptas para alcanzar el fin pretendido. Para este Tribunal, no constituye obstáculo alguno, en orden a confirmar la idoneidad de una ley, el escaso número de los casos perseguidos o sentenciados o el elevado número de la cifra oscura, ya que en estos casos el BVerfGE enfatiza el efecto de prevención

sentido, se pronuncia RODRÍGUEZ MONTAÑÉS, Delitos de peligro..., cit., pp. 305 y ss., la misma en RODRÍGUEZ MONTAÑÉS/PAREDES CASTAÑÓN, El caso de la colza: responsabilidad penal por productos adulterados o defectuosos, Valencia, 1995, pp. 195 y 196. 
general ${ }^{176}$. Y es el argumento al que recurre el BVerfG cuando se trata de justificar el adelantamiento de la protección penal a través de los delitos de peligro abstracto: el efecto de prevención general de estos tipos. Afirma que, debido a motivos de prevención general, está justificado que los tipos que contemplan la prohibición de traficar con productos derivados del cannabis amplíen la protección abarcando todos los comportamientos que «son generalmente aptos» para producir los peligros descritos ${ }^{177}$. El BVerfG parte de la premisa de que el fin de la Ley sobre estupefacientes (BtMG) es la de proteger la salud tanto de los individuos como de la colectividad frente a los peligros que se derivan de los estupefacientes y preservar a la sociedad, ante todo a la juventud, de la dependencia de las drogas ${ }^{178}$. A este fin sirven los preceptos de la BtMG y, para alcanzar este fin, el legislador no sólo incrimina aquellos comportamientos que son peligrosos para el individuo, sino que pretende la organización de la vida comunitaria (sozialen Zusammenlebens), de tal manera que quede libre de todos los efectos perjudiciales socialmente que se derivan del tráfico con estupefacientes. Además, el BVerfG considera que este fin que se pretendía cuando fue promulgada la BtMG se ha ampliado entre tanto de una forma considerable con los distintos convenios internacionales y, en especial, a través de la Convención de las Naciones Unidas sobre tráfico de estupefacientes y sustancias psicotrópicas de $1988^{179}$, siendo la BtMG «a la luz de esta Convención la contribución de Alemania al control internacional de estupefacientes y sustancias psicotrópicas, al control del comercio con estos estupefacientes y así como a la lucha del mercado ilegal de drogas y de las organizaciones criminales que en él participan» ${ }^{180}$.

En principio nada hay que objetar al hecho de que el legislador considere que la intimidación de todos los potenciales consumidores a través de la conminación legal sea más idónea/eficaz que la impunidad de estos comportamientos. El propio BVerfG reconoce, tras la exposición de una serie de datos sobre los efectos de los productos derivados del cannabis, que a pesar de que los peligros derivados de los mismos son menores que los que el legislador había considerado a la hora de promulgar la ley, todavía existen y no carecen de importancia. El legislador parte de que la totalidad del tráfico con productos derivados del cannabis, excepto el consumo, requiere un control estatal debido a los peligros que se derivan de la droga y del tráfico de drogas, tanto para el individuo como para la colectividad, y

176 BVerfGE 39, 1 (57); VOGEL, «Strafrechtsgüterschutz und Rechtsgüterschutz...», StV, 2/96, p. 113.

177 BVerfGE 90, 145 (184). Los peligros que según el BVerfGE derivan de las drogas son el peligro para la salud individual, el peligro de dependencia física y además la puesta en peligro de importantes intereses de la colectividad.

178 BVerfGE90,145(174).

179 Naciones Unidas ha reconocido, en especial en esta Convención, el merecimiento de pena de cualquier tráfico con estupefacientes porque la «salud y el bienestar de las personas se pone seriamente en peligro y las bases económicas, culturales y políticas de la sociedad se menoscaban».

180 BVerfGE 90, 145 (175) 
que la mejor forma de llevar a cabo ese control estatal es la de amenazar con pena todos los comportamientos relacionados con los productos derivados del cannabis.

Con el argumento ofrecido por el BVerfG para justificar la idoneidad de los delitos de peligro abstracto (prevención general), se plantea el problema, no exclusivo de los delitos de peligro abstracto, de la legitimidad de la prevención general para justificar el Derecho penal. En concreto, en relación con la prevención general negativa, las dudas de la doctrina se han centrado en la posibilidad de imposición de una pena a un sujeto que no es responsable del hecho, porque resulta necesario para evitar un mal social mayor. Pero también cabe plantearse hasta qué punto en las conminaciones penales abstractas la utilidad ha llevado al legislador a no respetar las exigencias derivadas de la proporcionalidad abstracta ${ }^{181}$. Tal y como plantea el Tribunal Constitucional español el juicio de idoneidad de una norma penal (SSTC 55/1996, 161/1997 y 136/1999), no habrá problema en afirmar la idoneidad de la prohibición contenida en el artículo $368 \mathrm{CP}$ para proteger el bien jurídico del que se trata, a través de la prevención general en el momento de la conminación penal, y de cualquier otro delito de peligro abstracto.

Como conclusión podemos afirmar, que serán idóneos los delitos de peligro abstracto para la protección de bienes jurídicos cuando, según la forma y la intensidad de los ataques, sea necesaria su protección frente a peligros abstractos; cuando se trate de prohibir comportamientos que no afectan de modo alguno al bien jurídico correspondiente serán inidóneos. Por otra parte, únicamente será idónea la prohibición penal de acciones peligrosas en abstracto cuando las distintas formas de actuación que se prohíben, normalmente supongan un peligro para el bien jurídico protegido y no cuando tan solamente en casos excepcionales puede suponer un peligro para el mismo ${ }^{182}$.

\section{V.2. B. Principio de necesidad y delitos de peligro abstracto}

\section{Principio de ofensividad y delitos de peligro abstracto}

Uno de los problemas a los que mayor atención ha prestado la doctrina, es el de la compatibilidad de los delitos de peligro abstracto con el principio de ofensividad. La razón no es otra que la imposibilidad, en un Ordenamiento jurídico presidido por el principio de ofensividad, de que la antijuricidad de un comportamiento se agote en la antijuricidad formal, sin que se exija la concurrencia de la antijuricidad material ${ }^{183}$.

181 SILVA SÁNCHEZ, Aproximación al Derecho..., cit., p. 215.

182 En el mismo sentido, GRASSHOF, BVerfGE 90, 145 (199 y ss.).

183 Tanto en el seno de la doctrina española como italiana, la crítica a los delitos de peligro abstracto ha girado en torno a la vigencia del principio de ofensividad y no al principio de culpabilidad, tal y como ha tenido lugar 
Las objeciones formuladas a esta categoría de delitos, atendiendo a la vigencia del principio de ofensividad, ha llevado a la doctrina a intentar dotar a estos delitos de antijuricidad material y conseguir la limitación de la punibilidad de los delitos de peligro abstracto. Con este fin, se han propuesto distintas soluciones reconducibles principalmente a dos: las opiniones orientadas a la producción de un resultado y aquellas que se orientan al comportamiento ${ }^{184}$. Es posible dotar de un contenido material a los denominados delitos de peligro abstracto y, por lo tanto, considerarlos compatibles con uno de los subprincipios del principio de proporcionalidad en sentido amplio: el principio de exclusiva protección de bienes jurídicos y el correlativo principio de ofensividad. Desde nuestro punto de vista, para que los delitos de peligro abstracto resulten compatibles con el principio de exclusiva protección de bienes jurídicos y con el principio de ofensividad es necesario: por una parte, que a través de los mismos se intente proteger bienes jurídicos merecedores de pena, es decir, constitucionalmente legítimos y dotados de una especial relevancia social, puesto que implican una ampliación muy importante de la tutela penal; por otra parte, que a través de los delitos de peligro abstracto se tipifiquen aquellas conductas que aparezcan como generalmente peligrosas para el bien jurídico que se trata de proteger, y no aquellas conductas que sólo en algunos casos aparecen como peligrosas; en último lugar, que en el caso concreto el comportamiento sea efectivamente peligroso para el bien jurídico protegido ${ }^{185}$, en el sentido de que aparezca como peligroso ex ante para el bien jurídico, sin necesidad de que se produzca un peligro concreto, porque de lo contrario faltará el substrato de la antijuricidad material del mismo. Ahora bien, el hecho de que la categoría de los delitos de peligro abstracto, en cuanto tal, no sea necesariamente contraria al principio de exclusiva protección y al correlativo principio de ofensividad, no quiere decir que en todos los casos en los que el legislador ha recurrido a esta técnica de tipificación haya respetado estos principios. Siempre que el legislador haya tipificado injustos meramente formales o de mera desobediencia, se puede afirmar que ha conculcado no sólo el principio de idoneidad, como ya hemos tenido ocasión de comprobar ${ }^{186}$, sino también el principio de ofensividad y, por ende, el principio de proporcionalidad en sentido amplio.

principalmente en el seno de la doctrina alemana. Vid. AGUADO CORREA, El principio constitucional..., cit., p. 301, n.p.p. 119.

184 BERZ, Formelle Tatbestandverwirklichung und materialer Rechtsgüterschutz, München, 1986, p. 101.Estas opiniones doctrinales están desarrolladas en AGUADO CORREA, El principio constitucional..., cit., pp. 302 a 325.

185 RODRÍGUEZ MONTAÑÉS, Delitos de peligro..., cit., p. 298, habla de la necesidad de que los delitos de peligro abstracto representen un peligro real para el bien jurídico.

$186 \mathrm{Al}$ analizar el principio de idoneidad ya afirmábamos que la técnica de los delitos de peligro abstracto no es idónea para proteger a los bienes jurídicos cuando se trata de prohibir comportamientos que no afectan de modo alguno al bien jurídico. 


\section{Principio de subsidiariedad y delitos de peligro abstracto}

La técnica de los delitos de peligro abstracto aparece como idónea para proteger determinados bienes jurídicos ante acciones generalmente peligrosas, requiriendo la vigencia del principio de subsidiariedad que una determinada exigencia político-criminal justifique la introducción de la anticipación de la protección penal que supone la introducción de este tipo de delitos ${ }^{187}$.

En principio, tal y como ha puesto de manifiesto TIEDEMANN, la utilización de la técnica de los delitos de peligro abstracto no contraviene el principio constitucional de proporcionalidad y más concretamente el principio de subsidiariedad, ya que la prohibición de ejecutar ciertas acciones corresponde a la idea de que el Derecho penal sólo puede prohibir que se lleven a cabo comportamientos peligrosos y no a la idea de impedir que se produzca un resultado dañoso ${ }^{188}$. El problema se plantea cuando se trata de justificar, desde la perspectiva del principio de subsidiariedad, aquellos casos en los que se procede a utilizar la técnica de los delitos de peligro abstracto sin existir una exigencia de naturaleza político-criminal, sino debido a la dificultad de incriminar aquellos comportamientos que atentan contra bienes jurídicos cuyos contornos no están claramente definidos, sino todo lo contrario ${ }^{189}$. No olvidemos que ya la mera amenaza de una pena supone un grave menoscabo de los derechos de los afectados.

Tampoco serían justificables, desde el punto de vista del principio de subsidiariedad, aquellos casos en los que el legislador decide acudir a la técnica de los delitos de peligro abstracto para incriminar meros injustos administrativos, si bien en estos casos lo realmente criticable no es que haya acudido a la técnica de los delitos de peligro abstracto, sino que haya acudido al Derecho penal cuando han fallado el resto de la medidas, y más concretamente las medidas administrativas. En estos supuestos, aun cuando se pueda afirmar que nos encontramos ante un bien jurídico merecedor de tutela penal, no se puede afirmar que esté necesitado de tutela penal. Por todo ello consideramos contrarios al principio de subsidiariedad, y, por lo tanto, vulneradores del principio de proporcionalidad en sentido amplio, todos aquellos delitos de peligro abstracto que no son más que meras incriminaciones de injustos administrativos, aquellos «delitos de peligro abstracto absolutamente coincidentes con las infracciones administrativas que también existen en las leyes administrativas ${ }^{190}$.

187 Vid. en este sentido GÜNTHER, «Die Genese eines Straftatbestandes...», JuS, 1978, p. 12; GRASSO, «Die Vorvelegung des Strafrechtsschutzes...», en Beiheft zur ZStW, 1987, p. 92.

188 TIEDEMANN, Poder económico y delito (Introducción al Derecho penal económico y de la empresa), Barcelona, 1985, pp. 33 У 34.

189 Cfr. GRASSO, «Die Vorverlegung des Strafrechtsschutzes...», en Beiheft zur ZStW, 1987, p. 89.

190 MUÑOZ CONDE, «El “moderno" Derecho penal...», La Ley, 1996, p. 1339. 


\section{Control constitucional del respeto del principio de necesidad}

El legislador, a la hora de decidir sobre la necesidad de amenazar con pena un determinado comportamiento, posee una prerrogativa de evaluación y decisión que sólo en una medida muy restringida puede ser objeto de control por parte del Tribunal Constitucional. El legislador es plenamente libre para decidir qué bienes jurídicos son merecedores de protección, de manera que únicamente cuando los bienes jurídicos que haya decidido proteger penalmente se puedan tachar de constitucionalmente ilegítimos o socialmente irrelevantes, puede declarar el precepto correspondiente desproporcionado y, por ende, inconstitucional ${ }^{191}$. Por lo tanto, todos aquellos delitos de peligro abstracto que protejan bienes jurídicos constitucionalmente ilegítimos y, lo que puede ser más normal, socialmente irrelevantes, deberán ser declarados desproporcionados. No olvidemos que la mera amenaza de una pena, debido a la desaprobación moral que conlleva, supone un menoscabo grave de los derechos personales y de la libertad de actuación, debiendo tener lugar dicho ataque únicamente cuando estén en juego intereses o bienes comunitarios importantes, cuya protección constituye la función del Derecho penal. Además, y aun cuando el Tribunal Constitucional no haga referencia a este aspecto en sus pronunciamientos sobre el principio de proporcionalidad ${ }^{192}$, tan sólo el comportamiento que implique la lesión o puesta en peligro de los mismos será merecedor de pena y, por consiguiente, cuando el injusto se agote en la mera contradicción formal de un precepto no será ni merecedor ni estará necesitado de pena, por lo que habrá que declarar la desproporcionalidad y la inconstitucionalidad de aquellos preceptos que incriminen comportamientos que no impliquen la lesión o la puesta en peligro del bien jurídico protegido.

El control constitucional sobre la existencia o no de medidas alternativas menos gravosas pero de la misma eficacia tiene un alcance y una intensidad muy limitadas. Cuando el Tribunal Constitucional alemán se planteó la necesidad de acudir a la técnica de peligro abstracto para la protección del bien jurídico protegido a través de los preceptos de la BtMG, recordó la prerrogativa de evaluación y de decisión, la cual, no puede ser objeto de control por parte del alto Tribunal. En este sentido, afirmó que si el legislador, en el caso de la BtMG, decide que para la protección del bien jurídico es necesario y más idóneo la intimidación de un gran número de potenciales consumidores a través de la prohibición del comercio con el cannabis que la supresión de la amenaza penal, ello es conforme con

191 En la Sentencia del Tribunal Constitucional de 2 de octubre de 1997 se afirma: «Esta primera aproximación al problema de la proporcionalidad suscitado podría incluso conducir ya a su resolución desestimatoria "si el sacrificio de la libertad que impone la norma persigue la preservación de bienes o intereses, no sólo, por supuesto, constitucionalmente proscritos, sino ya también socialmente relevantes"».

192 También pone de manifiesto el hecho de que el BVerfG no haga referencia a este aspecto cuando analiza la exigencia de necesariedad, GRASSHOF en el voto particular a la BVerfGE 90, 145 (202). 
la Constitución ${ }^{193}$. El BVerfG afirma que puesto que la discusión político-criminal sobre la disminución del consumo de cannabis no está cerrada y se puede realizar tanto a través del efecto de prevención general del Derecho penal como a través de la liberalización del consumo de cannabis, no se puede objetar nada desde el punto de vista constitucional al recurso a la técnica del peligro abstracto.

Desde luego, este mismo argumento podría ofrecer el Tribunal Constitucional español en lo que respecta a la necesidad de una prohibición como la contenida en el artículo $368 \mathrm{CP}$ o en cualquier otro delito de peligro abstracto, puesto que ambos Tribunales comparten el criterio de que el legislador tiene un amplio ámbito de decisión y prerrogativa.

En conclusión, si bien la prohibición penal de determinadas actuaciones peligrosas en abstracto es necesaria solamente cuando éstas no puedan evitarse o no pueda reducirse su potencial de peligro mediante otros medios menos incisivos, contando el Estado con más posibilidades de reacción cuanto más se adelante la prohibición de determinadas acciones (en abstracto peligrosas) en relación con las acciones lesivas, difícilmente el Tribunal Constitucional se pronunciará sobre la desproporcionalidad de la misma. Y ello a pesar de que en muchos casos, debido a la injerencia que el Derecho penal implica, aparece como innecesario si no existen datos incontestables sobre la menor intensidad coactiva y una funcionalidad manifiestamente similar a la obtenida por la prohibición de los comportamientos generalmente peligrosos para el bien jurídico ${ }^{194}$. Por este motivo es por el que difícilmente se podrá declarar que un delito de peligro abstracto es contrario al principio de subsidiariedad y, por consiguiente, desproporcionado e inconstitucional.

\section{V.2.A. Principio de proporcionalidad en sentido estricto y delitos de peligro abstracto}

\section{Compatibilidad de los delitos de peligro abstracto con el principio de proporcionalidad en sentido estricto}

En el ámbito de los delitos de peligro abstracto, el principio de proporcionalidad en sentido estricto adquiere una especial relevancia al encontrarnos ante una prohibición de actuación, redactada de una forma amplia ${ }^{195}$. En este análisis de la compatibilidad de los delitos de peligro abstracto con el principio de proporcionalidad en sentido estricto partiremos de lo afirmado por el Tribunal Constitucional alemán, debiendo aclarar que, aun cuando se

193 BVerfGE 90, 145 (183).

194 BVerfGE 90, 145 (182 y 183).

195 Sobre la importancia de este principio en relación con los delitos de peligro abstracto vid. el voto particular emitido por la juez GRASSHOF a la BVerfGE 90, 145 (203). 
refiere exclusivamente a algunos preceptos de la BtMG, desde nuestro punto de vista y tal como puso de manifiesto la juez GRASSHOF en el voto particular ${ }^{196}$ que formuló a esta sentencia, las consideraciones que lleva a cabo este Tribunal atinentes a la técnica del peligro abstracto, son extrapolables a todos aquellos preceptos penales en los que el legislador ha optado por esta técnica.

Cuando se trata de analizar la proporcionalidad en sentido estricto, el BVerfG señala que es preciso distinguir entre la prohibición de comercio con cannabis y, por otra parte, su refuerzo a través de la amenaza de una sanción penal, para las distintas formas de contravención del precepto - BVerfGE 90, 145 (183 y ss.)-. Por lo que respecta a la prohibición general de comercio con cannabis, señala que no cabe afirmar que sea contraria a la prohibición de exceso ya que se pretende hacer frente a los «peligros derivados de la droga para la salud de la sociedad y, en especial, para los jóvenes, así como proteger frente al peligro de dependencia psíquica de la droga y, por lo tanto, de la organizaciones criminales que dominan el mercado de la droga y de los efectos dañosos colectivos» [BVerfGE 90, 145 (184)]. Esta afirmación, según el Alto Tribunal alemán, también es válida cuando se trata de analizar la proporcionalidad de la amenaza con una sanción penal, puesto que no nos encontraríamos ante simples desobediencias de normas administrativas, es decir, ante injustos administrativos, sino que dichos comportamientos ponen en peligro intereses colectivos importantes, que son los que trata de proteger el legislador. Según el Tribunal Constitucional alemán, son motivos lo suficientemente justificados y claros los que llevan al legislador a considerar estas contravenciones como merecedoras y necesitadas de pena ${ }^{197}$. Tampoco habría nada que objetar al hecho de que el legislador haya decidido prescindir de la técnica de la lesión y del peligro concreto y se haya decantado por acudir a la técnica del peligro abstracto: los tipos penales sobre el comercio de productos derivados del cannabis pretenden llevar a cabo la protección de los correspondientes bienes jurídicos, abarcando todos los comportamientos que son generalmente idóneos para crear el peligro descrito, lo cual se justifica por motivos de prevención general ${ }^{198}$. Sin embargo, el Tribunal Constitucional reconoce que la propia naturaleza de una protección penal entendida de esta manera, implica que los tipos penales comprendan comportamientos que presentan una notable diferencia en relación con la clase y la intensidad del peligro que representa para el bien jurídico, y en relación con el contenido de injusto y de culpabilidad individual. El peligro para los bienes jurídicos comunitarios puede alcanzar una intensidad tan insignificante, si se atiende a las propiedades y clase de droga, la cantidad encontrada en el caso concreto, la clase de contravención 
ante la que nos encontramos, así como todas aquellas circunstancias relevantes en relación con el peligro, que los motivos de prevención general que son los que justifican la amenaza con una sanción penal, perderían peso.

Por todo ello resulta fundamental, desde nuestro punto de vista, la afirmación del BVerfG en la que señala que la pena podría aparecer como excesiva y, por ende, inconstitucional, si se atiende a los derechos del afectado, a la culpabilidad individual del autor y a los fines político-criminales de prevención especial que de ella se desprenden ${ }^{199}$. Como sabemos, la protección de los bienes jurídicos a través de la amenaza de una sanción penal se lleva a cabo mediante el mecanismo de la prevención general y de la prevención especial. Pero puede suceder que en los supuestos en los que la puesta en peligro de los bienes jurídicos sea insignificante, la prevención general, que es la que en los delitos de peligro abstracto juega un papel fundamental en la justificación de los mismos, ceda ante las necesidades de prevención especial, y atendiendo tanto a la culpabilidad insignificante y los predominantes fines de prevención especial, la pena puede ser desproporcionada ${ }^{200}$. Solamente en aquellos casos en los que nos encontremos ante comportamientos de una cierta peligrosidad para el bien jurídico protegido no deberán ceder las necesidades de prevención general frente a la especial ${ }^{201}$. Como vimos al exponer el principio de proporcionalidad en sentido estricto, en la conminación penal abstracta el legislador debe partir de criterios de proporcionalidad entre el injusto y la pena, pero también debe incorporar, aparte de criterios de prevención general, criterios de prevención especial. Por ello, el legislador debe prever una solución para aquellos casos en los que la pena imponible al autor aparezca como desproporcionada si se atiende tanto a la insignificancia del injusto como del grado de culpabilidad y a las exigencias de prevención especial.

No porque el legislador considere idóneo y necesario para alcanzar la pretendida protección de bienes jurídicos amenazar con una sanción penal el comercio prohibido con productos derivados del cannabis, sobra el examen de la proporcionalidad en sentido estricto. Muy al contrario, el tercer nivel del principio de proporcionalidad en sentido amplio pretende ser un control de signo opuesto de aquellas medidas que han sido consideradas idóneas y necesarias, en el sentido de si los medios utilizados, que son los que causan esa restricción de derechos fundamentales en los afectados, se encuentran en una relación de proporción con la protección del bien jurídico que a través de los mismos se pretende alcanzar. Este examen puede llevar a la conclusión de que un medio en principio idóneo y necesario para la protección del bien jurídico, no debe ser utilizado porque el menoscabo 
de derechos fundamentales del afectado que conlleva supera el aumento de protección del bien jurídico, de manera que la utilización de dicho medio de protección, puede ser reputado desproporcionado. Ello implica que bajo determinadas circunstancias se deja de proteger legítimamente el bien jurídico porque, de lo contrario, se produciría un menoscabo desproporcionado de los derechos fundamentales ${ }^{202}$.

Y esto puede ocurrir, desde nuestro punto de vista, no sólo en materia de drogas, sino en todos aquellos casos en los que el bien jurídico es amenazado de forma tan variada, que las puestas en peligro que padece son de muy diversa intensidad, resultando una tarea muy difícil, si no imposible para el legislador, prever distintas medidas de protección atendiendo al diverso grado de peligrosidad de una determinada acción. De manera que puede haber casos en los que el legislador considera que la técnica más adecuada y necesaria para la protección de bienes jurídicos es la de prohibir comportamientos generalmente peligrosos para el bien jurídico en cuestión, considerando el comportamiento de peligro abstracto en cuanto tal como merecedor y necesitado de pena, sin que en principio exista posibilidad de «privilegiar punitivamente» aquellas formas de actuación que revisten una peligrosidad escasa. Como recordaremos, en virtud de la vigencia del principio de fragmentariedad, el límite inferior del principio de proporcionalidad en sentido amplio será traspasado por aquellos comportamientos amenazados con pena que no aparezcan como tales, suficientemente peligrosos para el bien jurídico protegido, pero no por aquellos otros que son considerados como generalmente peligrosos, aun cuando en el caso concreto nos encontremos ante un comportamiento escasamente peligroso. En tanto que los elementos o requisitos del principio de proporcionalidad en sentido amplio de idoneidad y necesidad justifiquen la incriminación de comportamientos generalmente peligrosos y los trate de una manera indiferenciada como merecedores y necesitados de pena, el tercer elemento o requisito del principio de proporcionalidad en sentido amplio, el principio de proporcionalidad en sentido estricto, adquiere aún mayor relevancia.

Cuanto más amplia es la tipificación que lleva a cabo el legislador penal de las conductas peligrosas en abstracto para el bien jurídico, más en serio ha de tomarse la posibilidad de que queden comprendidos por el tipo comportamientos que sólo resultan peligrosos para el bien jurídico de una manera insignificante. $Y$ es para tales situaciones en las que el contenido de injusto es irrelevante, para las que el legislador ha de prever soluciones que permitan evitar un excesivo gravamen, un excesivo perjuicio al afectado por la persecución y, en su caso, evitar la imposición de la pena prevista en el correspondiente precepto, al cual en principio no cabe hacer reparo alguno. Pero no olvidemos que el principio de proporcio- 